\title{
Theoretical Foundations of Efficiently Organizing Production Processes: Using the Example of Combining Organizational Forms of Component Manufacture and Internal Transport
}

\author{
Anne-Katrin Schroeder, ${ }^{1}$ Theodor Nebl, ${ }^{1}$ and Christian Mainzinger ${ }^{2}$ \\ ${ }^{1}$ Institute of Production Management, University of Rostock, Ulmenstraße 69, 18057 Rostock, Germany \\ ${ }^{2}$ Departmental Branch Federal Police, Federal University of Applied Administrative Sciences, \\ Ratzeburger Landstraße 4, 23562 Lübeck, Germany \\ Correspondence should be addressed to Anne-Katrin Schroeder; schroederak@hotmail.com
}

Received 6 February 2014; Revised 3 September 2014; Accepted 16 September 2014; Published 22 October 2014

Academic Editor: Yoonho Seo

Copyright (C) 2014 Anne-Katrin Schroeder et al. This is an open access article distributed under the Creative Commons Attribution License, which permits unrestricted use, distribution, and reproduction in any medium, provided the original work is properly cited.

\begin{abstract}
This paper examines the problem of efficient production processes organization down to subprocesses levels. Subtasks of production within subprocesses necessitate a specific set of requirements for production organization. Through particular features and their respective characteristics, these requirements are further systemized and described as process types. The main manufacturing process "component manufacture" and its connected production support service "internal transport" have been chosen as examples to show relevant organizational principles and forms. From this baseline and together with a decision algorithm, selected organizational options and a combination thereof shall lead to theoretically optimized solutions which meet all predefined requirements. A multilevel organizational alignment model lays out interdependencies of combined process type-oriented organizational forms. Methods of comparative organizational profile analysis in support of reengineering approaches are systemized and further developed towards resulting organizational adaptations.
\end{abstract}

\section{Introduction and Methodical Approach}

Implementation of production programs necessitates task splitting. As a result, subtasks and subprocesses are created, then leading to technical and organizational specializations in order to solve the tasks effectively and efficiently. This brings out the question of which specific subtasks have to be addressed in the respective subprocesses. Once subtasks are defined, requirement profiles can be derived and subsequently categorized in general process types. For each of such process types the decision has to be made concerning how the concrete realization of subtasks can be organized within the respective subprocesses. Therefore, organizational ability profiles have to be developed, which also need to be closely linked to the corresponding requirement profiles. This approach forces the value added main manufacturing processes (component manufacture and assembly) as well as the production support services to be integrated into the organizational design.

The example of component manufacture (as part of the main manufacturing processes) and internal transport (as part of the production support services) shall be used to describe resulting theoretical organizational principles and the design of organizational forms. In addition, considerations are made related to combination variants of organizational principles and organizational forms of component manufacture and internal transport, including the respective ability profiles these combinations have. Furthermore, a comparative profile analysis of process type's requirements and the abilities of combined organizational forms of component manufacture and internal transport is conducted, based on which precise organizational solutions in accordance with 

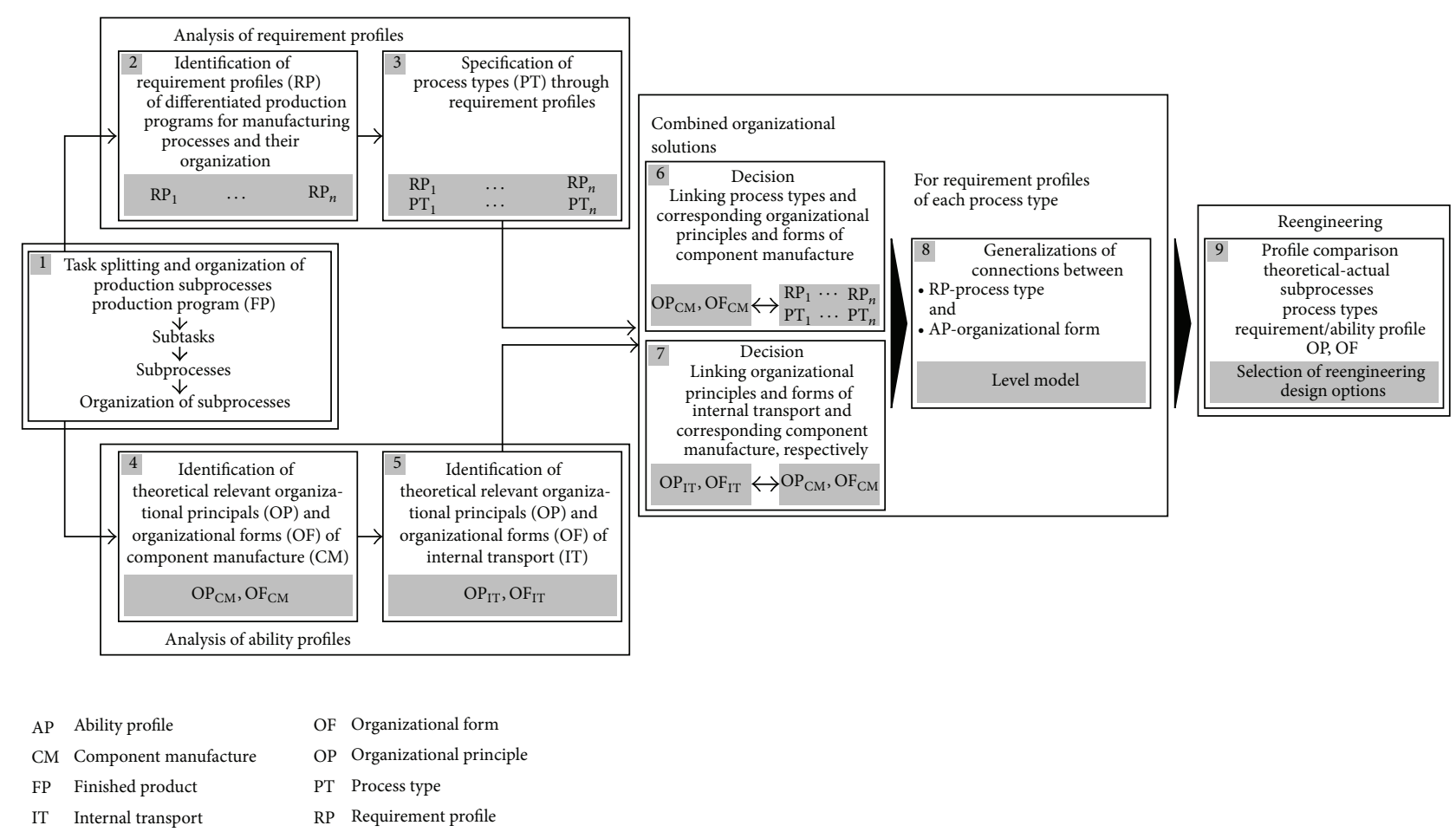

FIGURE 1: Methodical approach.

specific requirement profiles can be identified as well as efficiency expectations in the subtasks of production processes. Linkages and interdependencies are generalized in a multilevel model.

Based on the approaches described above, the fit equitability of the subprocesses and organizational forms in relation to the modified production tasks are revised through a comparative analysis. The results of this comparison bring out necessary measures for reorganization as part of reengineering and provides for efficient production processes.

The methodical approach is illustrated in Figure 1.

\section{Theoretical Frameworks of Production Processes Organization}

Frese et al. [1] postulate that there is no uniform view on the term "organization." However, Scheibler [2], for example, defines organization, in a rather generic way, as a goaloriented design of systems. For Grochla [3] organization is a goal-oriented structure of elements which are connected with each other in a specific way. For the purposes of this paper, such a generic understanding of organization shall suffice, because the focus is very specifically on efficient production process organization.

For efficient realization of tasks, a system as a whole has to be divided through a pragmatic and creative approach into subsystems on the basis of a microanalysis [4, 5] aiming at addressing subtasks within the subprocesses that have been created for this purpose [6]. Furthermore it is obvious that a system has to be structured through different levels of hierarchy ("Organisationsstruktur" [7] and "formale
Struktur" [8]) to be able to design coherent processes. This then defines division of labor and specialization [4].

The depth and width of organizing the subprocesses impact, for instance, on subsystems of selected functional areas. Implementation of such core processes is very central for the success of a company [4]. Because organization is part of process management, it especially focuses on core processes of production.

Bea and Schweitzer [4] define the following criteria to identify core processes:

(i) high importance for
(a) problem-solving or satisfaction of external and internal customers,
(b) core competencies of the company,
(c) product quality,
(d) reliability of production;

(ii) high cost-intensity and capital lockup;

(iii) long duration of processes.

These criteria show that the production process is a core process. Therefore, systematic structuring of as well as specific organizational designs for all subprocesses of production processes in the context of their interaction for execution of tasks is necessary. It is believed that company process as a whole as well as individual core processes can be further broken down into nearly indefinite numbers of steps [4]. All subprocesses have to be identified to a point where production processes for the manufacturing of components, assemblies, and finished products take place at their lowest level of line organs 
within their respective functional production area [5]. This is where the main manufacturing processes-component manufacture and assembly-occur and value is added, plus where the production support services are relevant. These services include, for example, internal transport, internal storage, maintenance, and information management. They are used for spatial and temporal transformation of work items, as backup for capacity as needed and task execution control.

Objects of organizational arrangements in these subprocesses are

(i) production tasks (or subtasks as a result of division of labor) of the production program;

(ii) potential factors of production in terms of manpower and assets which realize the production process through their capacity;

(iii) the repetitive factor material that is purposefully changed by the action of the potential factors of production to produce components and finished products (see also [9]).

With productivity being the overall aim, the interaction of manpower, assets, and materials has to be organized in accordance with the subprocesses of production [10]. Therefore, it is necessary to match the dynamically changing requirements of production programs and its derived subtasks from the technical and organizational point of view. Finding the best combination of elements is the mission of organization [11]. The combination of elementary factors of production has to be organized in a way that a spatial framework for the solution of production tasks is established and that the timing of the processing of work items and their transformation in the manufacturing process can be defined.

The spatial framework is usually linked to a static elementary factor of the subprocesses in question. Very often this is the asset. This also raises the question of the techni$\mathrm{cal} /$ technological and capacitive realization of organizational solutions of subprocesses, levels of mechanization as well as automation, resulting from task splitting and specialization of the production tasks that have to be solved [12]. The temporal framework is determined by possible variants of passing components from one work station to another along the technological processing or assembling sequence of spatially deployed assets as well as through the capacity requirement of each working cycle at each work station.

Spatial transformation of work items is done by internal transport. Therefore, the spatial framework is used to arrange the set-up of assets and where manpower realizes working operations [9]. Temporal transformation of work items aiming at bridging intervals in the progress of manufacturing or cross-overs to other organizational units of the subprocesses are typically resolved by internal storage.

Growing uncertainty regarding the development and complexity of business environment $[12,13]$ becomes noticeable, for example, through

(i) product type development,

(ii) production technology development, (iii) changes in requirement and demand, or

(iv) shortage of resources.

This leads to the fact of shorter product life cycles as well as dynamic changes in production programs, subsequently leading to process dynamics. It forces a company to respond with process developments which can easily adapt to the changed requirements. This applies not only to technical/technological adjustments, but particularly to changes of organization [4] and is, for instance, realized through innovation strategies as a "special kind of change" [12].

Considering aspects of economic efficiency, focus on organization of the main manufacturing processes alone, as done in the past, is not enough. This approach must be complemented by the organization of involved production support services. Without these services, the manufacturing process does not function. From an organizational point of view, manufacturing processes and production support services have to be treated holistically together with seamlessly fitting combinations of the same in order to find requirement based solutions for optimized economic results.

On one hand, the design of such combination variants of production organization requires the identification of all relevant (theoretical) organizational principles and forms of the main manufacturing processes together with their production support services, whilst on the other hand, a requirement-oriented selection and combination of the aforementioned principles and forms of organization is needed. Organization as a tool has to meet various requirements [4], which have to be met by the production program and derived subtasks in structured subprocesses.

The following features have critical influence on the tasks which have to be solved [14]:

(i) the quantity aspect and therefore the number of identical products that have to be produced;

(ii) the type of order placement for products by diverse customers;

(iii) the level of standardization of the products that have to be produced;

(iv) the structure of the products that have to be produced;

(v) the proportion of externally procured product components.

These features form a set of requirements and they impact-inter alia - on the organizational design in terms of flexibility and continuity. The flexibility of an organizational form is a precondition to meet different or changing requirement profiles within the production processes without the need to change the organizational form.

The term flexibility finds a considerable number of definitions and theoretical deliberations revolving around it (e.g., [15-20]). In our opinion, flexibility can be defined as the ability to adapt production in relation to changing markets [21]. From this perspective, quantity and quality differentiations are needed. 
Quantitative flexibility can be understood as the ability to adjust production to volume changes of uniformed product types. This is relevant for

(i) changes and adaptations of capacity utilization,

(ii) mobilization of capacity reserves.

Qualitative flexibility in turn is the ability to adjust production to changing product types. This relates to capabilities of the production process in terms of

(i) alternative utilisation of repetition factors,

(ii) alternative utilisation of potential factors,

(iii) activation of alternative combinations of elementary factors.

The essential precondition for flexibility is the ability of an organizational form to realize varying technological processing sequences. The two most relevant dimensions are product flexibility and volume flexibility ([15], see other flexibility dimensions in [16]). In this paper, continuity is characterized as the ability of uninterrupted processing of work items in the manufacturing process. If customers accept standardized products, then fixed continuous production systems are useful. In order to remain competitive, increasingly flexible technologies are necessary [12].

The complete set of requirements for the organization of subprocesses of production determines the requirement profile. On the one hand, existing organizational forms of production processes can be subject to a critical appraisal based on this set of requirements, whilst on the other hand, such set of requirements provide orientation for practical organization. Ultimately it is always about assessing the target effectiveness (efficiency) of alternative organizational forms [4] and about the identification of the best organizational variant for the solution of specific production tasks so that standard procedures can be determined in order to ensure maximum efficiency [4].

The organization of value added production subprocesses

(i) provides the basic organizational structure (after task splitting) that leads to the formation of necessary subprocesses with their respective posts [6] and departments [5],

(ii) creates within each subprocess the specific procedures and ways in which the relevant elementary factors of production (manpower, assets, and materials) can be combined from a spatial, temporal, and technical perspective. This configuration approach brings out the organizational form of the particular subprocess [22].

The organizational forms of production support services take effect in this structure and they support the value added processes. The selection and design of their organizational principles and forms takes place downstream to the organization of the main manufacturing processes. This means that the organization of the main manufacturing processes determines the organizational principles and organizational forms of production support services.
Each organizational form of the main manufacturing processes and the production support services is shaped by the combination of spatial, temporal, and technical organizational principles [21-28]. Based on the ability profiles of organizational principles and organizational forms of all involved subprocesses, combined solutions have to be found and formed, which fit the requirement profiles of components, modules, and component classes best [29]. In this paper, the term "component class" is used for (single) components which fall into one category with constructive and/or technological similarities which allow treating these components equally in the manufacturing process.

\section{Requirement Profiles for Component Classes in Differentiated Process Types}

What follows goes into the details of classifications and requirement profiles on micro-organizational levels. However, a company must have a much wider (contextual) competitive strategy (e.g., $[30,31]$ ) from which subsequent operational solutions such are then derived. For the purpose of this paper the production program is the starting point to determine tasks to be solved and task splitting. Varying types of customers define their specific needs and demands. This results in (a) heterogeneous versus homogeneous sales and production programs and (b) diverse versus uniformed product types with varying production quantities that may also include a strong customer focus versus "customer distance."

3.1. Features for Process Type Characteristics. The requirement profile is particularly set through output-oriented features starting with the products to be obtained and the production programs which are then followed by the manufacturing and procurement process [32]. From outputoriented features of the requirement profile, throughput and input-oriented features are derived. However, it must be observed that individual features can be assigned to several areas of the macrostructure. An overview of relevant features and its characteristics gives the morphological box in Figure 2.

Central to features and their characteristics-which specify requirements of the organizationally envisaged production tasks of manufacturing processes-is the production type [29] which is closely linked to the other features as well.

The production type brings out the quantity aspect of identical products of the production program as well as the variant diversity of the offered basic products. This results in homogeneous (one product, with a large quantity and a large variant diversity) versus heterogeneous production programs (many different product types with different quantities to different product types with a quantity of down to only one as well as a very limited variant diversity). In this regard, the envisaged finished product is examined.

Subject to the quantity of identical primary products, two categories have to be looked at: (a) individual and small series production of heterogeneous programs and (b) series and mass type production of homogeneous programs. The first category (individual production, small series production) 


\begin{tabular}{|c|c|c|c|c|c|}
\hline Features & \multicolumn{5}{|c|}{ Feature characteristics } \\
\hline Production type & $\begin{array}{l}\text { Individual } \\
\text { production } \\
\text { IP }\end{array}$ & $\begin{array}{l}\text { Small series } \\
\text { production } \\
\text { SSP }\end{array}$ & $\begin{array}{r}\text { Type pro } \\
\mathrm{T}\end{array}$ & & $\begin{array}{c}\text { Mass production } \\
\text { MP }\end{array}$ \\
\hline $\begin{array}{l}\text { Type of order } \\
\text { placement }\end{array}$ & $\begin{array}{l}\text { Contract production } \\
\text { CoP }\end{array}$ & \multicolumn{2}{|c|}{$\begin{array}{c}\text { Mixed production } \\
\text { MiP }\end{array}$} & \multicolumn{2}{|c|}{$\begin{array}{l}\text { Warehouse production } \\
\qquad \mathrm{WaP}\end{array}$} \\
\hline $\begin{array}{l}\text { Level of product } \\
\text { standardization }\end{array}$ & $\begin{array}{l}\text { Customer- } \\
\text { individual } \\
\text { products } \\
\text { CIP }\end{array}$ & $\begin{array}{l}\text { Customer- } \\
\text { individualized } \\
\text { products } \\
\text { CZP }\end{array}$ & \multicolumn{2}{|c|}{$\begin{array}{c}\text { Customer- } \\
\text { anonymous } \\
\text { standard products } \\
\text { with supplier } \\
\text { specific variants } \\
\text { CAPsv }\end{array}$} & $\begin{array}{c}\text { Customer- } \\
\text { anonymous } \\
\text { standard products } \\
\text { without variants } \\
\text { CAPwv }\end{array}$ \\
\hline $\begin{array}{l}\text { Structure of } \\
\text { products }\end{array}$ & $\begin{array}{c}\text { Multipart } \\
\text { complex products } \\
\text { MCP } \\
\end{array}$ & \multicolumn{2}{|c|}{$\begin{array}{c}\text { Multipart } \\
\text { simple products } \\
\text { MSP } \\
\end{array}$} & \multicolumn{2}{|r|}{$\begin{array}{l}\text { Minor-part } \\
\text { products } \\
\text { MPP }\end{array}$} \\
\hline $\begin{array}{l}\text { Ratio of external } \\
\text { procurement }\end{array}$ & $\begin{array}{c}\text { External procurement } \\
\text { insignificant } \\
\text { EPI }\end{array}$ & $\begin{array}{r}\text { External } \mathrm{p} \\
\text { a lin }\end{array}$ & $\begin{array}{l}\text { rement on } \\
\text { scale }\end{array}$ & & $\begin{array}{l}\text { rnal procurement } \\
\text { mostly } \\
\text { EPM }\end{array}$ \\
\hline
\end{tabular}

Figure 2: Features and feature characteristics leading to differentiated process types (based on [14, 29]).

relates to mostly customized products (essentially determined by the client configuration and ordered accordingly), which are produced in very small quantities, whilst category (b) relates to series production with both, large quantity and a distinct variant diversity, which then provides for customerindividualized products (customer chooses from possible variants, which are provided by the producer) [29].

A third category (type production) relates to large quantities of customer-anonymous standard products with very limited variant diversity. The manufacturer provides basic products, which are in terms of construction and technology all nearly identical, with only very few product variants, such as color or materials, being used. The customer is not involved in the formation of variants and production. He chooses his product variant by purchase (e.g., on the retail market).

In mass production (fourth category) large quantities of customer-anonymous standard products are produced without any variations.

In principle, the aforementioned speaks for the need to have flexible and/or continuous manufacturing processes, which must be met by the production organization.

The production type is closely connected to two further relevant features with impact on the manufacturing process and its organization, namely, (a) type of order placement and (b) level of product standardization.

Both features factor a particular customer perspective into the respective considerations. Standardization levels are interdependent with gradations of specific customer requirements, ranging from fully standardized products to individually customized products, something which at the same time also affects issues of product variant diversity.

Type of order placement varies between contract production at one end and warehouse production at the other end. Contract production is triggered by individual customers with their individually customized products [29]. These products are typically actualized in individual production, in exceptional cases also in small series production. Warehouse production includes large quantities of largely customeranonymous products with an either limited variant diversity (type production) or no variants (mass production).

Customer individualization approaches in series production often integrate both customer-anonymous and customer-individualized process elements into the manufacturing process and thus combine flexibility and continuity [29]. Customer individualization of production programs with small quantities sets the basis for special process organization allowing for flexibility, whilst in contrast to that customer anonymity of programs with large quantities of each product type requires an organizational design of the processes that primarily aim at ensuring continuity.

Elevated levels of product individualization increase the number of variants in homogeneous production programs and reduce the quantity of products in heterogeneous production programs towards individual production. In contrast to that, production of customer-anonymous standard products allows for quantities that move up towards type or mass production.

Once again and applicable for both aforementioned features, the finished product is the key reference. The production type, the type of order placement, and the level of standardization determine not only the quantity but also the variant diversity of finished products.

The fourth feature is the structure of a product. This perspective brings a shift of focus from the finished product (primary requirement) to single product components and modules (secondary requirement). It identifies the diversity and number of components contained in a product of the production program and thus defines the product complexity. The aggregation of all product components with largely identical constructional and/or technological and organizational 
demands in the process of component manufacture (e.g., required manufacturing methods, technological processing sequence, capacity requirement for each work station, and component flow) creates the basis for the establishment of specific component classes and task splitting.

Regardless of the number and diversity of the finished products, component classes of the secondary requirement ultimately determine the specific requirement profiles of the organizational subprocesses.

To address issues related to component classes' tasks, core processes are brought into a hierarchical order with an increasing level of detail. In doing that, main processes are analyzed and divided into subprocesses, operations, and process steps [4]. Each component class has its own requirement profile, which forms the basis for technical specialization and the design of organizational ability profiles for each subarea of production.

Requirements for the organizational design of subprocesses of components within the same class are usually identical. For component classes with differentiated requirement profiles different subprocesses must be designed and organized. This applies only to those component classes, which ensure a high level of capacity utilization of those subprocesses. Component classes without their own subprocesses must be produced within subprocesses that have been created for other component classes. This results in special requirements regarding flexibility and capacity of such subprocesses.

The fifth feature, ratio of external procurement of product components, is derived from the structure of the product. This feature affects the organizational design in terms of continuity and/or flexibility.

The manufacturer must decide which program components/modules are fabricated internally ("make") or bought externally from a third party ("buy"). Thinking in terms of a continuum in between the poles "make" and "buy," leaning towards "make" will result in an increase in manufacturing a (greater) variety of components and a focus on flexibility. Leaning towards "buy" will reduce complexity and "manufacturing depth" as well as the variety of components. This creates an opportunity for a company to focus on core competencies and align its production processes in order to meet increasing demands for continuity through a reduction of manufacturing depth.

3.2. Requirement Profiles of Process Types. All features and feature characteristics discussed define quantity and variant diversity of production programs [28] and they require process designs, which ultimately, if brought to the extreme, lead to the consequence to choose between continuity and flexibility. Efficient production solutions will have to factor this into the organizational design of subprocesses.

Each feature has differentiated feature characteristics. This reveals the scope and diversity of requirements for the organizational process design of a production program. Based on these features and their substantive links, Figure 3 presents a general framework for requirement profiles. Specific requirement profiles can be generated from various combinations of feature characteristics.
The features of process types-production type, type of order placement, and level of product standardizationresult in requirements for production organization. As can be seen in our model these features relate to primary requirements (in terms of finished products), but they are especially identifiable through quantity, variant diversity, and customer orientation.

The structure of a product as well as the ratio of external procurement of product components are features resulting in requirements for production organization that are initially determined by the secondary requirements (thus in terms of components and modules). These features then further point to components and their component classes.

The characteristics of the process types requirements for production organization are directed at the

(i) constructional and/or technological similarity of component parts,

(ii) necessary manufacturing methods,

(iii) direction of production flow in connection with the technological processing sequence as well as

(iv) required capacity and the respective rate of utilization.

Production programs (and their requirements) with the characteristics of the above discussed features are eventually aiming at organizational solutions which have their center of gravity in continuous or flexible production settings. The realization of such production settings must be based on organizational principles and forms which have the respective ability profiles.

3.3. Feature Combinations and Relating Process Types. Different combinations of features and feature characteristics lead to the identification of theoretically and practically relevant process types. In addition, the exclusion of practically irrelevant or unacceptable combinations is critical for the formation of process types. Figure 2 showed the principal mechanisms.

In order to create process types, combinations of features, which are characteristic for small- and medium-sized enterprises (SME), are used. This is based on identified interdependencies of selected features. The number of combinations $(z)$ results from $z=m_{1} * m_{2} * \cdots * m_{n}$ with $m=$ number of possible characteristics per feature and $n=$ number of features [33].

Features and feature characteristics have been taken from a research project in which 60 companies in the metalworking industry in Mecklenburg-West Pomerania participated [34]. The respective interdependencies matrix [14] can be seen in Table 1.

In order to bring together the high number of resulting basic cases with process types suitable for organizational purposes, a cluster analysis is required. For the clustering of nominal-scaled features-determined as shown in the morphological box (see Figure 2) - the hierarchic agglomerative 


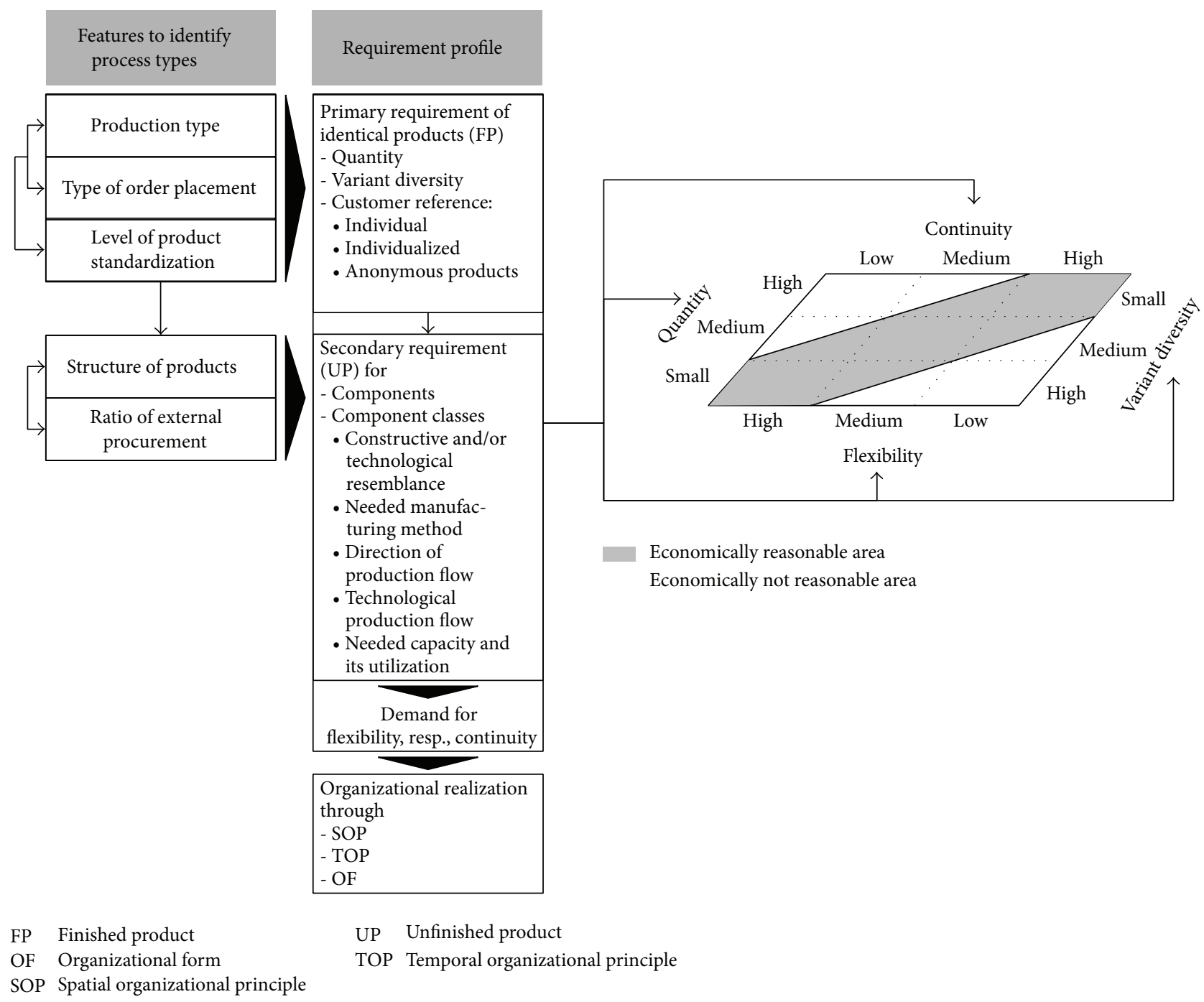

FIGURE 3: General requirements for the organization of production processes (based on [14, 28]).

approach (Ward-method) seems particularly suitable for this (see [14] and annex 2 in [14]). This method allows filtering out homogenous yet distinctive groups. Subsequently, such defined groups lead to specific requirements for the configuration of the production organization.

As a result four typical combination variants have been identified and referred to as process types [14, 35]. Each process type has its specific requirement profile (see Figure 4). A different approach with equal results can be found in the “Aachener PPS-Model” [36].

Research related to the metalworking industry in Mecklenburg-West Pomerania [34] has shown that in smalland medium-sized enterprises (SME) process type $1(82 \%$ [14]) is predominantly represented in comparison with types 2-4 (6\% each).

The morphological box shows that a shift of combined feature characteristics towards the right side of the box results in a categorization away from process type 1 to process types $2-4$.
3.4. Production Organization and Process Types. The following correlations between the four process types and organization of production can be derived.

(i) The features which define the requirement profile of process type 1 stand for small quantities of identical products (individual production) with high variant diversity and customer individuality, which has to be secured by highly flexible manufacturing processes. It can be expected that not only is capacity utilization highly variable, but also elements of component classes may need different manufacturing methods in a varying technological processing sequence $[22,37-$ 41].

(ii) The features which define the requirement profile of process type 2 stand for small quantities of identical products (series production) with a relatively high 
TABLE 1: Interdependencies matrix of features and feature characteristics [14].

\begin{tabular}{|c|c|c|c|c|c|c|c|c|c|c|c|c|c|}
\hline & & \multicolumn{3}{|c|}{ Structure of products } & \multicolumn{3}{|c|}{ Type of order placement } & \multicolumn{3}{|c|}{ Production type } & \multicolumn{3}{|c|}{ Ratio of external procurement } \\
\hline & & $\mathrm{MCP}$ & MSP & MPP & $\mathrm{CoP}$ & $\mathrm{MiP}$ & $\mathrm{WaP}$ & IP & SP & MP & EPI & EPL & EPM \\
\hline \multirow{4}{*}{$\begin{array}{l}\text { Level of product } \\
\text { standardization }\end{array}$} & CIP & $\mathrm{X}$ & $\mathrm{X}$ & & $\mathrm{X}$ & & & $\mathrm{X}$ & $\mathrm{X}$ & & $\mathrm{X}$ & $\mathrm{X}$ & \\
\hline & CZP & $\mathrm{X}$ & $\mathrm{X}$ & $\mathrm{X}$ & $\mathrm{X}$ & $\mathrm{X}$ & & $\mathrm{X}$ & $\mathrm{X}$ & & $\mathrm{X}$ & $\mathrm{X}$ & \\
\hline & $\mathrm{CAP}_{\mathrm{SV}}$ & $\mathrm{X}$ & $\mathrm{X}$ & $\mathrm{X}$ & $\mathrm{X}$ & $\mathrm{X}$ & $\mathrm{X}$ & & $\mathrm{X}$ & $\mathrm{X}$ & $\mathrm{X}$ & $\mathrm{X}$ & $\mathrm{X}$ \\
\hline & $\mathrm{CAP}_{\mathrm{WV}}$ & & $\mathrm{X}$ & $\mathrm{X}$ & & $\mathrm{X}$ & $\mathrm{X}$ & & $\mathrm{X}$ & $\mathrm{X}$ & & $\mathrm{X}$ & $\mathrm{X}$ \\
\hline \multirow{3}{*}{$\begin{array}{l}\text { Structure of } \\
\text { products }\end{array}$} & MCP & - & - & - & $\mathrm{X}$ & $\mathrm{X}$ & $\mathrm{X}$ & $\mathrm{X}$ & $\mathrm{X}$ & & $\mathrm{X}$ & $\mathrm{X}$ & $\mathrm{X}$ \\
\hline & MSP & - & - & - & $\mathrm{X}$ & $\mathrm{X}$ & $\mathrm{X}$ & $\mathrm{X}$ & $\mathrm{X}$ & $\mathrm{X}$ & $\mathrm{X}$ & $\mathrm{X}$ & $\mathrm{X}$ \\
\hline & MPP & - & - & - & $\mathrm{X}$ & $\mathrm{X}$ & $\mathrm{X}$ & $\mathrm{X}$ & $\mathrm{X}$ & $\mathrm{X}$ & $\mathrm{X}$ & $\mathrm{X}$ & \\
\hline \multirow{3}{*}{$\begin{array}{l}\text { Type of order } \\
\text { placement }\end{array}$} & $\mathrm{CoP}$ & - & - & - & - & - & - & $\mathrm{X}$ & $\mathrm{X}$ & & $\mathrm{X}$ & $\mathrm{X}$ & $\mathrm{X}$ \\
\hline & $\mathrm{MiP}$ & - & - & - & - & - & - & & $\mathrm{X}$ & $\mathrm{X}$ & $\mathrm{X}$ & $\mathrm{X}$ & $\mathrm{X}$ \\
\hline & WaP & - & - & - & - & - & - & & $\mathrm{X}$ & $\mathrm{X}$ & $\mathrm{X}$ & $\mathrm{X}$ & $\mathrm{X}$ \\
\hline \multirow{3}{*}{ Production type } & IP & - & - & - & - & - & - & - & - & - & $\mathrm{X}$ & $\mathrm{X}$ & \\
\hline & SP & - & - & - & - & - & - & - & - & - & $\mathrm{X}$ & $\mathrm{X}$ & $\mathrm{X}$ \\
\hline & MP & - & - & - & - & - & - & - & - & - & & $\mathrm{X}$ & $\mathrm{X}$ \\
\hline
\end{tabular}

CIP: customer-individual products; $\mathrm{CAP}_{\mathrm{SV}}$ : customer-anonymous standard products with supplier specific variants; $\mathrm{CAP}_{\mathrm{WV}}$ : customer-anonymous standard products without variants; CZP: customer-individualized products; EPI: external procurement insignificant; EPL: external procurement on a limited scale; EPM: external procurement mostly; MCP: multi-part complex products; MPP: minor-part products; MSP: multi-part simple products; CoP: contract production; MiP: mixed production; WaP: warehouse production; IP: individual production; MP: mass production; SP: series production; X: combination is theoretically meaningful/practically relevant.

Process type 1

\begin{tabular}{|l|}
\multicolumn{1}{|c|}{ Features } \\
\hline Production type \\
\hline $\begin{array}{l}\text { Type of order } \\
\text { placement }\end{array}$ \\
\hline $\begin{array}{l}\text { Level of product } \\
\text { standardization }\end{array}$ \\
\hline Structure of products \\
\hline $\begin{array}{l}\text { Ratio of external } \\
\text { procurement }\end{array}$ \\
\hline
\end{tabular}

Process type 3

\begin{tabular}{|l|}
\multicolumn{1}{|c|}{ Features } \\
\hline Production type \\
\hline $\begin{array}{l}\text { Type of order } \\
\text { placement }\end{array}$ \\
\hline $\begin{array}{l}\text { Level of product } \\
\text { standardization }\end{array}$ \\
\hline Structure of products \\
\hline $\begin{array}{l}\text { Ratio of external } \\
\text { procurement }\end{array}$ \\
\hline
\end{tabular}

\begin{tabular}{|} 
Feature characteristics \\
\begin{tabular}{|c|c|c|c|}
\hline IP & \multicolumn{2}{|c|}{ SSP } & \multicolumn{2}{|c|}{ TP } & MP \\
\hline CoP & \multicolumn{2}{|c|}{ MiP } & \multicolumn{2}{|c|}{ WaP } \\
\hline CIP & \multicolumn{2}{|c|}{ CZP } & \multicolumn{2}{c|}{ CAPsv } & CAPwv \\
\hline MCP & \multicolumn{2}{|c|}{ MSP } & MPP \\
\hline EPI & \multicolumn{2}{|c|}{ EPL } & EPM \\
\hline
\end{tabular}
\end{tabular}

CAPsv Customer-anonymous standard products with supplier specific variants

CAPwv Customer-anonymous standard products without variants

EPL External procurement on a limited scale

MiP Mixed production

TP Type production

CIP Customer-individual products

MP Mass production

SSP Small series production

IP Individual production
Process type 2

\begin{tabular}{|c|c|c|c|c|}
\hline Features & \multicolumn{4}{|c|}{ Feature characteristics } \\
\hline Production type & IP & SSP & $\mathrm{TP}$ & MP \\
\hline $\begin{array}{l}\text { Type of order } \\
\text { placement }\end{array}$ & $\mathrm{CoP}$ & \multicolumn{2}{|c|}{ MiP } & WaP \\
\hline $\begin{array}{l}\text { Level of product } \\
\text { standardization }\end{array}$ & CIP & CZP & CAPsv & CAPwv \\
\hline Structure of products & MCP & & & MPP \\
\hline $\begin{array}{l}\text { Ratio of external } \\
\text { procurement }\end{array}$ & EPI & & & EPM \\
\hline
\end{tabular}

Process type 4

\begin{tabular}{|c|c|c|c|c|}
\hline Features & \multicolumn{4}{|c|}{ Feature characteristics } \\
\hline Production type & IP & SSP & $\mathrm{TP}$ & MP \\
\hline $\begin{array}{l}\text { Type of order } \\
\text { placement }\end{array}$ & $\mathrm{CoP}$ & \multicolumn{2}{|c|}{$\mathrm{MiP}$} & WaP \\
\hline $\begin{array}{l}\text { Level of product } \\
\text { standardization }\end{array}$ & CIP & $\mathrm{CZP}$ & CAPsv & CAPwv \\
\hline Structure of products & MCP & \multicolumn{2}{|c|}{ MSP } & MPP \\
\hline $\begin{array}{l}\text { Ratio of external } \\
\text { procurement }\end{array}$ & EPI & \multicolumn{2}{|c|}{ EPL } & EPM \\
\hline
\end{tabular}

FIGURE 4: General features for the representation of different requirement profiles of process types (based on [14, 29]). 


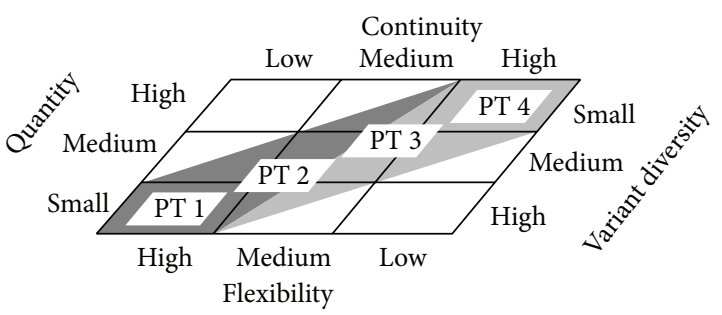

FIgURE 5: Positioning process types (based on [14, 28]).

variant diversity and distinct customer individualization. This should lead to a flexible manufacturing process design, though it may include to some extent also continuous manufacturing process elements, whilst capacity utilization levels are fluctuating. A variety of manufacturing methods together with a varying technological processing sequence may become necessary $[22,37,42,43]$.

(iii) The features which define the requirement profile of process type 3 stand for large quantities of identical products (type production) with a relatively small and customer-anonymous variant diversity in a mostly continuous manufacturing process. Capacity utilization is relatively constant. Components within component classes regularly require identical manufacturing methods in the same technological processing sequence where individual work stations may be left out (skipping individual work stations) [22, 37, 38, 4143].

(iv) The features which define the requirement profile of process type 4 are very large quantities of identical products (mass production) with a small, customeranonymous variant diversity in a highly continuous manufacturing process. Capacity utilization is largely constant. Components within component classes require identical manufacturing methods in the same technological processing sequence going through all work stations as needed (without skipping individual work stations) [22, 37-43].

The above described impact of process types and production organization is further illustrated by Figure 5 .

The position of the process types in the above chart points toward their requirements for the organization of production. Hereafter, the question arises: how the demands for flexibility, or continuity, of process types can be reconciled with the respective needs in terms of quantities and variant diversity.

The intended categories of technological processing sequences are the connecting link between the requirement profiles of component classes within selected process types on the one hand and the organization of production within relevant subprocesses on the other hand. The technological processing sequence is task-oriented and it specifies the sequential arrangement of a production line with its spatially arranged work stations and manpower.

With regard to the factor of (product types) flexibility, the configuration of varying technological processing sequences is a requirement of critical importance. Within this approach every production task (production lot or components per component class) runs on an individual "course" through the spatially arranged stationary assets and manpower. However, the one decisive and integrative criterion is not the "course" of a production task as such, but the manufacturing methods required for all production tasks.

Turning to the factor of continuity, the creation of identical technological processing sequences is essential. Production orders pass through the arranged stationary assets and manpower on identical "courses" (regardless whether all stationary assets along the production line are needed in any one manufacturing process or not). An integrated approach requires bringing together the simultaneous realization of two criteria: (a) direction of production flow and (b) manufacturing methods.

As a result from these findings and the issue of combination of feature characteristics of the process types in the morphological box (see Figure 4), it is believed that the specific requirements for the production organization can only be determined after component classes have been defined. Types of process-related component classes are specified by the following features (see Table 2).

From a perspective of production organization, an efficient production is conditional to mainly two factors: (a) usage of differentiated technological requirements of process types and their component classes and (b) application of specific-and coordinated-spatial and temporal organizational principles in whatever combination required. This equally applies for both, organization of the main manufacturing processes and organization of production support services.

\section{Ability Profiles of Organizational Principles and Forms - A Theoretical Analysis}

This chapter shall explain the (theoretical) relevance of organizational principles and organizational forms of the main manufacturing process "component manufacture" and its transport processes together with their ability profiles. In addition, how differentiated combinations of organizational principles result in corresponding organizational forms will be explained. This will then end up in (theoretically) organizational concepts with distinct ability profiles for various requirement profiles of the respective process types.

4.1. Organization of the Main Manufacturing Process "Component Manufacture". The organization of the main manufacturing process "component manufacture" is determined by spatial, temporal, and technical organizational principles and organizational forms [22, 44, 45].

4.1.1. Spatial Organizational Principle of Component Manufacture. The spatial organizational principle of component manufacture defines the spatial arrangement of work stations (assets) in the manufacturing process [46]. We distinguish the shop principle from the product principle with the group 
TABLE 2: Specific features of different process types.

\begin{tabular}{|c|c|c|c|c|}
\hline Features & Process type 1 & Process type 2 & Process type 3 & Process type 4 \\
\hline $\begin{array}{l}\text { Number of components } \\
\text { per lot }\end{array}$ & Small & Small & High & Very high \\
\hline Variant diversity & High & Relatively high & Relatively small & Small \\
\hline Customer reference & Customer individual & Customer individualized & Customer anonymous & Customer anonymous \\
\hline $\begin{array}{l}\text { Technological } \\
\text { resemblance of } \\
\text { components }\end{array}$ & High & High & High & Identical components \\
\hline $\begin{array}{l}\text { Constructive resemblance } \\
\text { of components }\end{array}$ & Restrictive & Restrictive & High & Identical components \\
\hline $\begin{array}{l}\text { Needed manufacturing } \\
\text { methods }\end{array}$ & $\begin{array}{l}\text { Variety of different } \\
\text { manufacturing } \\
\text { methods }\end{array}$ & $\begin{array}{l}\text { Limited number of } \\
\text { different manufacturing } \\
\text { methods }\end{array}$ & $\begin{array}{l}\text { Mostly all identical } \\
\text { manufacturing } \\
\text { methods }\end{array}$ & $\begin{array}{l}\text { Identical } \\
\text { manufacturing } \\
\text { methods }\end{array}$ \\
\hline $\begin{array}{l}\text { Direction of production } \\
\text { flow }\end{array}$ & Varying & Varying & Identical & Identical \\
\hline $\begin{array}{l}\text { Technological processing } \\
\text { sequence }\end{array}$ & Varying & Varying & Identical with skipping & $\begin{array}{l}\text { Identical without } \\
\text { skipping }\end{array}$ \\
\hline $\begin{array}{l}\text { Capacity requirement of } \\
\text { components per working } \\
\text { cycle }\end{array}$ & Extremely fluctuating & Fluctuating & Extensively constant & Constant \\
\hline Capacity utilization & Extremely fluctuating & Fluctuating & $\begin{array}{l}\text { Extensively } \\
\text { consistently high }\end{array}$ & Consistently high \\
\hline Flexibility/continuity & $\begin{array}{l}\text { Demand for flexibility } \\
\text { first, then demand for } \\
\text { continuity }\end{array}$ & $\begin{array}{l}\text { Demand for flexibility } \\
\text { first, then demand for } \\
\text { continuity }\end{array}$ & $\begin{array}{l}\text { Demand for continuity } \\
\text { first, then demand for } \\
\text { flexibility }\end{array}$ & $\begin{array}{l}\text { Demand for } \\
\text { continuity first, then } \\
\text { demand for flexibility }\end{array}$ \\
\hline
\end{tabular}

principle, the serial principle, and the single user principle as spatial organizational principles [22, 47].

The following paragraphs explain spatial organizational principles and their interconnected ability profiles.

(i) The shop principle (procedural principle) is characterized by the fact that all assets which belong to the same manufacturing method are summarized spatially in one workshop. It is perfect for customized multiple complex products which are manufactured in small quantities but with a great variant diversity in individual production or small series production with a relatively low external purchase of components. Contract production builds the core of this kind of production. The shop principle is closely connected with a varying technological processing sequence which ensures high flexibility in product types.

(ii) The group principle can be looked at as transient form or a cross-over from the shop principle to the product principle. Assets of different manufacturing methods are locally concentrated. The specific arrangement depends on the production work flow for the component classes. Compared with the shop principle, a significant reduction of variant diversity can be observed together with increased quantities of identical products. The respective type of order placement works on the basis of contract and/or warehouse production settings. The group principle contributes to high flexibility through varying technological processing sequences. (iii) The serial principle is characterized by the fact that all assets which are required for the production of a small component assortment are spatially centralized and arranged in such a manner that production operations required for all components are carried out in an identical and repetitive manufacturing sequence. Applying this principle is predestinated for standard products without variants, respectively, with vendorspecific variants of the product that are classified as multiple simple or multiple complex products. Such products are produced in large quantities through type or mass production. The type of order placement tends towards warehouse production with substantial external purchase of components. The requirement profile is closely linked with an identical technological processing sequence for production tasks that can be executed with or without skipping of work stations. A high degree of continuity has priority over distinct flexibility.

(iv) The single user principle ensures high continuity as well as distinct flexibility. Its limitation lies in the technical ability to integrate various manufacturing methods in one work station. Pending the integration options of possible manufacturing methods, either identical and/or varying technological processing sequence can be applied.

4.1.2. Temporal Organizational Principle of Component Manufacture. The temporal organizational principle of component 
manufacture determines the system of physical movements of components in batch production during the manufacturing process (see [48]). It is further determined by the configuration of the technological cycle. Temporal organizational principles with and without passing on of components have to be distinguished.

The flow of components (passing on components) can be framed in a serial parallel or combined progression [22, 46, 47].

The following paragraphs describe temporal principles and interconnected ability profiles as they relate to the creation of organizational forms.

(i) In serial progressions complete lots get transported along a varying technological processing sequence from one work station to another upon completion. Components of the lot have a constructional and/or technological similarity. The combined components that make a lot belong to different finished products which have to be produced in small quantities in contract production. Each lot has its specific route through the setting of work stations of an organizational unit. The direction of production flow of each lot is different. This procedure corresponds with the need for flexibility in product types. By moving complete lots through the production line the number of single transport actions between work stations is reduced. The length of transport routes naturally depends on the spatial organizational principle in which the variants of passing on components are realized: When applying the shop principle, longer routes are necessary. Contrary to that, shorter routes are possible if the group principle is applied. Production process delays of components which have passed one work station may occur (laytimes) until the next work station is ready to receive the component, respectively, until the transport gets started. The component processing at each work station is carried out without interruption. The serial progression and the shop and group principles are closely related and show interdependencies.

(ii) In parallel progressions usually single components of a production lot are routed through the production line configuration which by comparison with serial progression shortens the duration of the technological cycle (and consequently the expected throughput time). The construction of product components as such and the engineering sequencing of product components of a particular lot remain identical. Single product components find themselves in the same finished products and they are produced in large quantities. Usually warehouse production can be assumed. The technological processing sequence and the direction of production flow are equal for all components of the same lot. With this being so, the parallel progression fulfills especially the requirement for process continuity. If, at least nearly, equal processing times per work station are achievable, separate transport operations of the components of each lot can be realized. If the processing times at work stations differ, product components have to be mainly moved further through the production line configuration in sublots. Diverging processing durations in relation to consecutive working cycles can lead to production disruptions (downtimes and waiting times). The parallel progression and the serial principle are closely related and show interdependencies.

(iii) Combined progressions (also referred to as "hybrid configurations" [49]) consist of elements of the serial and parallel progression. They can be used for similar configurations as the parallel progression. The planning assumption is that processing durations significantly differ. Therefore transport of product components takes place in transport lots of varying sizes. Identical technological processing sequences are preferable in such configurations as it allows skipping work stations (that are unnecessary for a particular lot). Downtimes and waiting times at work stations can be avoided but laytimes are inevitable. Combined progressions are closely related and interconnected with the serial principle.

(iv) The principle without passing on components is linked with the single user principle. Any type of production component can be processed under this principle, if technical feasibility and integrated manufacturing methods are provided accordingly. Any type of product component can be processed under this principle.

4.1.3. Classical and Modern Organizational Forms of Component Manufacture. A classical organizational form of component manufacture is comprised of a combination of spatial and temporal organizational principles (see Figure 6) $[22,46]$. They are divided in primary and derivative (also possible) organizational forms and those which have no theoretical and practical relevance. The derivative organizational forms should only be used in exceptional cases of the corporate practice. In comparison with the primary organizational forms it is expected that they realize significantly worse economic outcomes.

This paper focuses on primary organizational forms. In general, organizational forms bring out specific abilities in terms of flexibility and continuity. The respective correlations are provided in Figure 7.

Modern organizational forms add technical organizational principles of component manufacture to combined spatial and temporal organizational principles. Such organizational forms are based on classical organizational forms of component manufacture with integrated technical measures at various levels of sophistication [48] in terms of mechanization and automation of engineering subsystems in the engineering system [22], which extends to and is inclusive of processing, transport, storage, and handling systems [28].

In Section 3 of this paper, five features and feature characteristics of process types were explained and put into context. To further support the selection of technical organizational principles for the envisaged organizational 


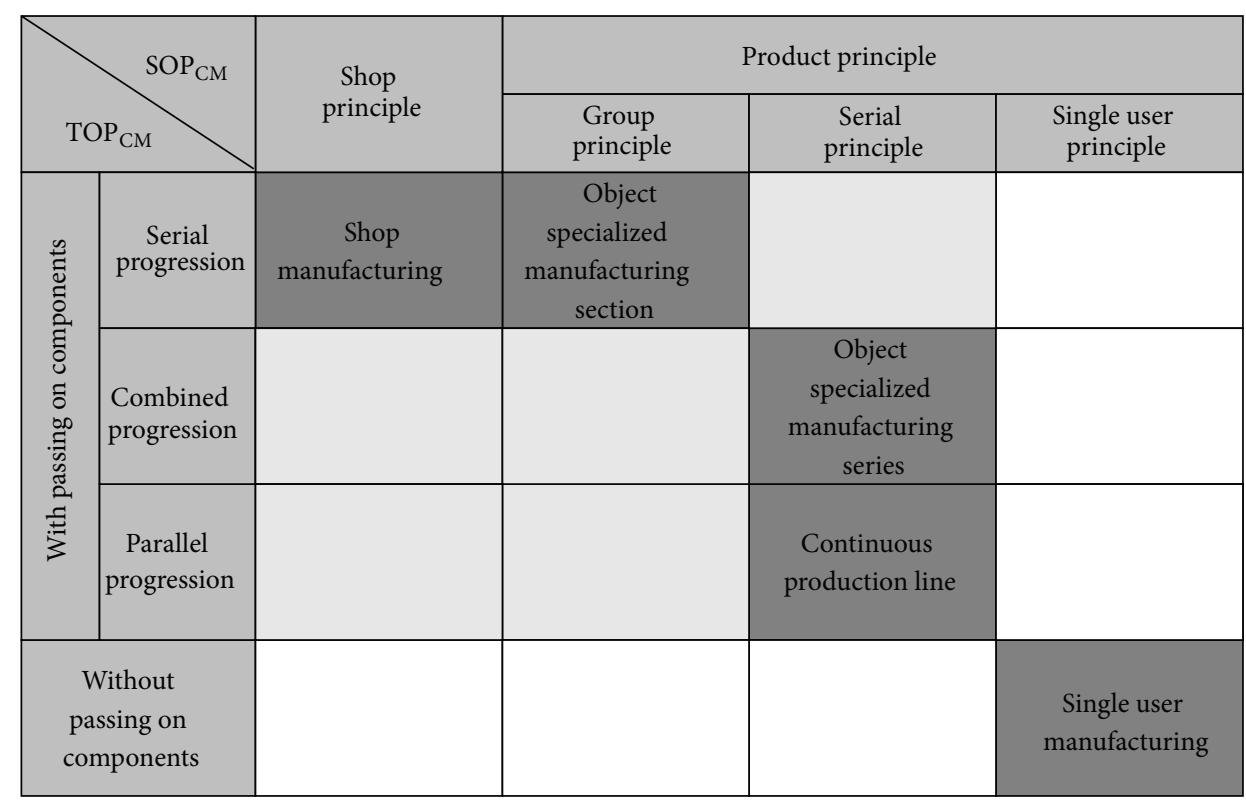

$\mathrm{SOP}_{\mathrm{CM}}$ Spatial organizational principle of component manufacture

TOP $_{\mathrm{CM}}$ Temporal organizational principle of component manufacture

Primary (theoretical and practical relevant) organizational form of component manufacture

Derivative (possible) organizational form of component manufacture

No relevant possible combination

FIgURE 6: Classical organizational forms of component manufacture (based on [22]).

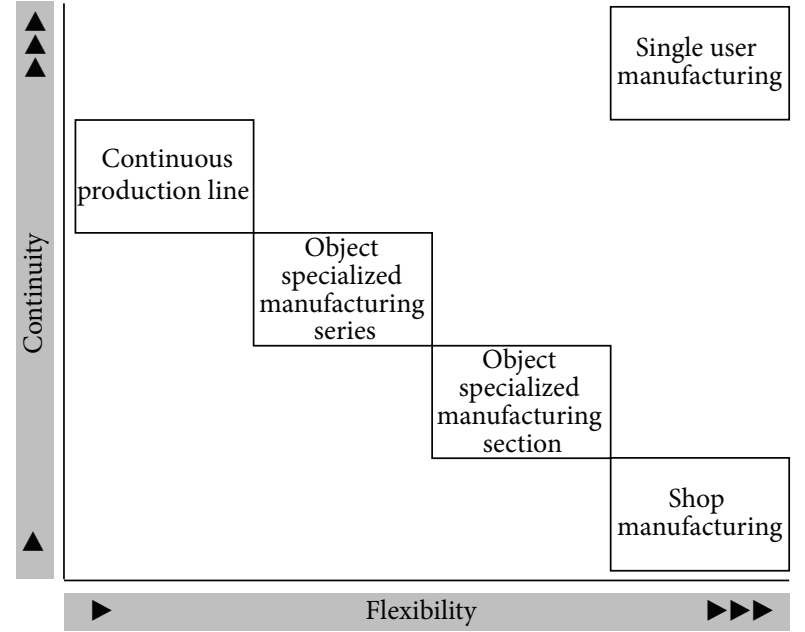

FIGURE 7: Potentials in flexibility and continuity of classical organizational forms [22].

design, three additional process features need to be collated to the aforementioned five. These three features are

(i) qualification levels of the employees;

(ii) degree of automation of the manufacturing processes $[50]$;

(iii) degree of specialization of the assets [24].
Complex production tasks are determined by continuously changing and diverse working operations in heterogeneous production programs with significant flexibility elements. They require, from a process automation perspective, manual and/or mechanized production processes which are executed by highly qualified employees operating allpurposes machines.

Homogeneous production programs with constant repetitions of nearly identical working operations and high output quantities allow for less qualified staff and machines with a high specialization. Such a work force has to only execute a limited number of specific work operations in at least partially or even fully automated manufacturing processes.

The ideal classical organizational solution needs to encompass requirement profiles and process type-related technical solutions at the appropriate level of applied technological sophistication. In this regard, the selection of an organizational solution will depend on the envisaged production tasks (quantity, variant diversity) and subsequently the resulting consequences in terms of flexibility and continuity in the manufacturing process [22]. The various automation potentials that are shown in Figure 8 further illustrate the relevant correlations.

A key distinguishing feature of modern organizational forms of component manufacture is their ability to provide for flexibility and continuity in the production process. Flexibility and continuity are influenced by (a) automation of work operations and (b) technical realization of one stop component manufacturing. Technology driven modern 


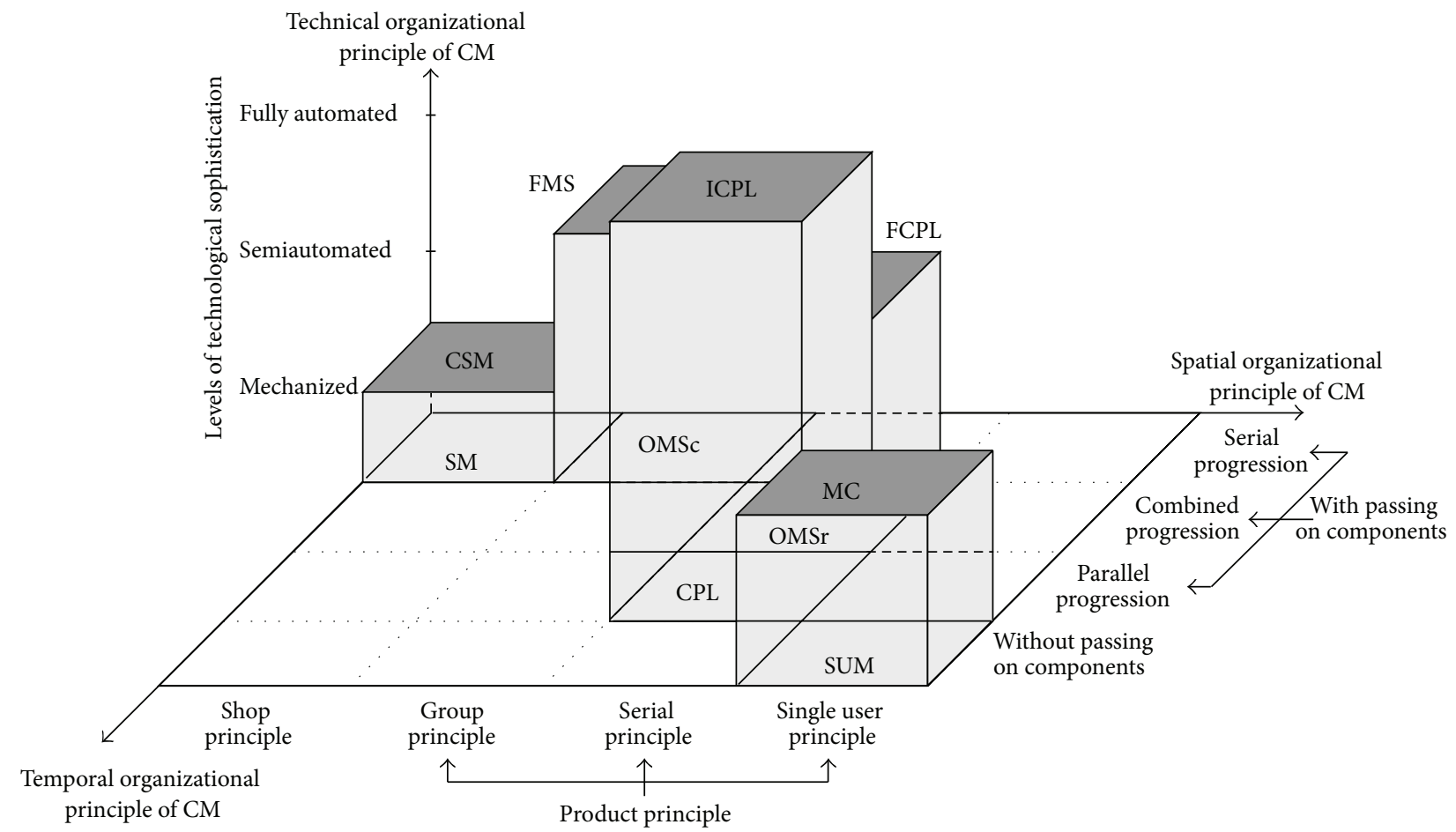

Modern organizational forms of component manufacture CSM Continuous shop manufacturing

FMS Flexible manufacturing system

FCPL Flexible continuous production line ICPL Inelastic continuous production line MC Machining center

SUM Single user manufacturing

CM Component manufacture

FIGURE 8: Classical and modern organizational forms of component manufacture (based on [22]).

organizational forms have the ability to diffuse the conflict between continuity and flexibility.

A literature review shows extensive discussions regarding flexibility and continuity of production processes. Under the term flexible automation (e.g., [51-57]) a relatively equal orientation towards both process characteristics finds preference. The specific setting of the production organization is essential for an either (more) flexible or continuous production flow. The requirement profile of the respective process type determines which organizational principles and forms must be used to the greatest extent possible in accordance with correlating ability profiles.

As a result of their specific features and feature characteristics (see Figure 2), process type 1 predominately supports flexibility, whilst process type 4 does so regarding continuity. Improvements in continuity usually lead to a reduction of flexibility and vice versa. Process types 2 and 3 give evidence to this.

Process type 2 can be regarded as an advancement of process type 1. Its flexibility decreases because of limited numbers of manufacturing methods-which encompass production of fewer component classes-by comparison with process type 1 . Its continuity increases because of the reduction of production process delays caused by spatial proximity of machines and work stations.

Process type 3 can be looked at as a precursor of process type 4 and its organization. Its continuity decreases as a result of a reduced production sequence. This reduction is caused by the need to cover a wider spectrum of products and variants which makes it necessary to skip work stations in an otherwise similar technological processing sequence. At the same time however, qualitative flexibility increases with more product options and variants.

Demand for (more) flexibility in production processes normally implies that the work force requires a broader qualification profile with specific skillsets and capabilities. Continuity in production processes usually leads to an increased level of specialized mechanization/automation of production systems. Extremely high levels of flexibility result in low levels of consistency and vice versa. Combined organizational solutions containing significant flexibility and continuity components in one single context will lead to a situation where both of these parameters will be at the far end from the possible optimum. Modern tailored to suit organizational forms benefit from a specific choice of technical organizational principles, thus optimizing flexibility 


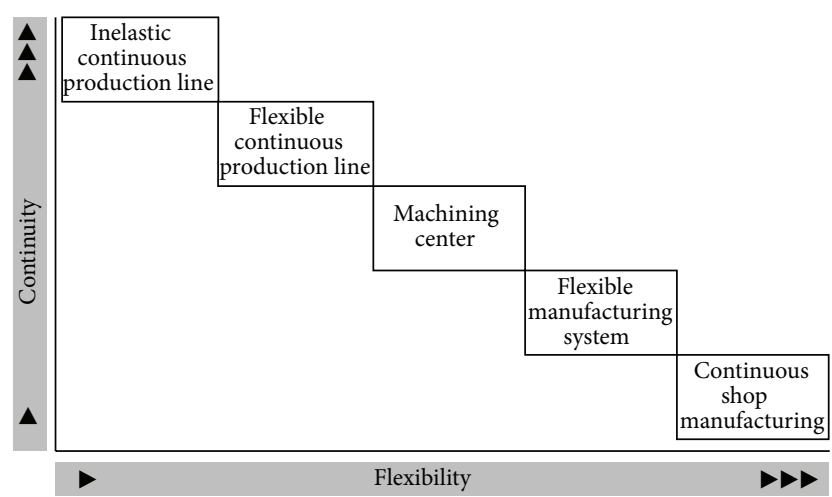

FIGURE 9: Potentials in flexibility and continuity of modern organizational forms (based on [21]).

and continuity of the process in accordance with particular strategic, technical, and operational requirements.

In the context of integrated manufacturing methods, continuous shop manufacturing (CSM), flexible manufacturing systems (FMS), and the machining center (MC) are contributing to high flexibility, but when compared with continuous production lines, they are naturally less effective with regard to continuity characteristics [22]. Sectional object specialized manufacturing and shop manufacturing form the basis for modern organizational forms "continuous shop manufacturing" and "flexible manufacturing systems" which are highly flexible though limited with regard to continuity. Flexible continuous production lines (FCPL) which are particularly focused on quantity flexibility and less focused on product type flexibility have their strong point in continuity. Inelastic continuous production lines (ICPL) have the highest degree of continuity with little quantitative flexibility and insignificant flexibility in product types (see Figure 9).

Traditionally, such problems are discussed under the term "Dedicated Manufacturing Lines" (DML) [13] or "Dedicated Manufacturing System" (DMS) [20], but the respective discussions seem to not include-or are at least not explicit enough in relation to-considerations revolving around combinations of spatial, temporal, and technical organizational principles as they have been described above. Only this allows for more differentiated approaches to optimum organizational solutions and their subsequent practical application in terms of required hard- and software to ensure effective and efficient production capacity and flexibility (e.g., [58]). Equally, the development of "Flexible Manufacturing Systems" (FMS), [59] "Reconfigurable Manufacturing Systems" (RMS) [20, 60, 61], and Agile Manufacturing Systems (AMS) [62] or further variations of such systems (e.g., "Cellular Manufacturing Systems" (CMS), [63]) needs to be founded on and informed by defined basic organizational principles from the outset.

Understanding the theory of organizational forms of component manufacture can inform process- and requirement profile-related decision making.

4.2. Organization of the Production Support Service "Internal Transport". Production support services are vital for core production operations and associated managerial steering and control functions [4], for example, production assets maintenance and preservation. More information regarding services can be found in [64-73]. Additional information related to industrial services can be obtained from sources [74-90].

Internal production logistics is also an essential production support service for the production process. Interfaces are between (a) procurement logistics and incoming goods store and (b) end product storage and distribution logistics. Key components of internal logistics are internal storage and internal transport (also referred to as material handling system (MHS), [91, 92]).

For the purpose of this paper internal transport realizes the spatial transformation of elementary factors of production in the operational performance process [23,48]. Central to this issue is the raw material or the work item used (if stationary potential factors of production assumed). In work-sharing production systems the physical movement of the elementary factor "material" from work station to work station is by its nature an essential production support service organized in accordance with the technological processing sequence.

Production support services can be described as complementary immaterial production provisions from industrial companies which have positioned themselves in close proximity to manufacturing. Such services can be viewed as enablers for the main manufacturing processes. They contribute to high productivity through an effective and efficient production process. Production support services can be systemized in accordance with (a) their respective operational areas in which they function; (b) their organizational relation with relevant production factors; and (c) their particular proximity to manufacturing (see also $[64,93,94]$ ).

In furtherance of one key subject matter of this paper, namely, organization of the main manufacturing process "component manufacture" and organization of the production support service "internal transport," the following principle considerations and contextual issues are stated.

Organizing in general-which of course also includes the organization of production processes-is task and output of the dispositive production factor organization and for this reason a production support service. This is inclusive of a task-oriented design of spatial and temporal organizational principles applied in the main manufacturing processes/subprocesses. The objective is to attune organizational know how (ability profiles) to the requirement profiles of production programs, which then lead to a corresponding factory layout. Based on such fundamental deliberations (amongst many others though), ultimately a corresponding factory layout can be developed which in a very advanced format has been examined in detail by Wiendahl et al. using the example of the Modine Wackersdorf $\mathrm{GmbH}$ that was awarded "best assembly" in Germany $2006[95,96]$.

Internal transport is an elementary factor-oriented production support service. It contributes indirectly to the added value of the main manufacturing processes for which it is an indispensable precondition (as also stated by Chittratanawat and Noble [97] although with another focus). Organizing 


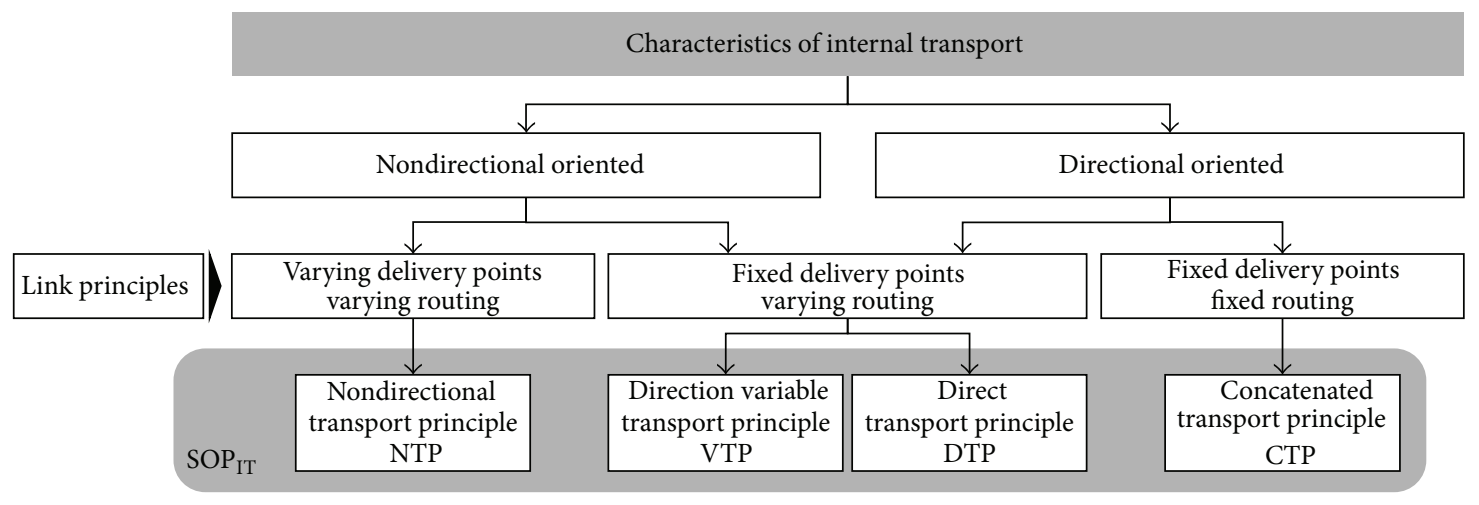

FIGURE 10: Spatial organizational principles of internal transport ([23] based on [21]).

the internal transport is in two ways a production support service-both, from an organizational perspective and from the transport perspective as such. It includes the design of spatial and temporal organizational principles and organizational forms of internal transport which take place in the organizational forms of the main manufacturing processes, including movements to and from temporary storage. In our model, material management and logistics serve as a provider of such production support services. Demand for such services is defined by the process owner or an internal customer. In this context, the work item (component, module, or material) can be looked at as an external factor.

Options for the organizational design of internal transport are considered below. As stated before, the organizational forms of internal transport as well as the classical organizational forms of component manufacture need to be based on spatial and temporal organizational principles. Their different combinations bring out various organizational options to be further examined.

\subsubsection{Spatial Organizational Principle of Internal Transport.} The applied spatial organizational principle of internal transport determines the direction of internal transport. It is further determined by the specific routing along delivery points. We distinguish between directed and nondirected transports. In this context, production tasks provide reference for such transport related considerations.

From a spatial point of view, it makes sense to differentiate between transports with either fixed or varying delivery points with a fixed or varying routing, respectively. If the routing is fixed, the (fixed) delivery points get passed by the production tasks in an identical sequence. Specific route connections in between delivery points need to be installed. In case of varying routings the delivery points get passed by an individual design of transport processes in accordance with a varying sequence. Flexible route connections in between delivery points need to be installed [23]. Even though the combinations of possible variants of routings and delivery points result in four potential interconnections of spatial link principles for internal transport, only three spatial link principles remain, because by logic the grouping of varying routing and fixed delivery points is irrelevant.
Together with these spatial link principles and their underlying characteristics, the spatial organizational principles of internal transport also address the directive or nondirective nature of the transport solution. Figure 10 further illustrates how these aspects interrelate.

Organizational design options which are based on spatial organizational principles of internal transport in connection with associated ability profiles can be generalized as follows [23].

(i) The nondirectional spatial transport principle (NTP) is applied where production tasks involve varying delivery points (work stations) in a task specific and varying routing without a general routing direction. As a rule, there are only a limited number of delivery points at the production site along the task specific transport routing. This is typical for heterogeneous production programs.

(ii) The direction variable spatial transport principle (VTP) applies in a setting, where production tasks are executed along fixed delivery points of the transport system, yet in a varying routing as dictated by the respective individual production step and without a general routing direction. Typically, delivery points of the transport system are located at the production site and along the task specific transport routes of the production tasks.

(iii) Object specialized spatial organizational principles of component manufacture are based on homogeneous production programs with large quantities of identical products. Such conditions are predestined to also apply direct (DTP) and concatenated transport principles (CTP). Usually, the same technological processing sequence without skipping work stations occurs in the concatenated transport principle. Where the direct transport principle is applied, different processing times and identical technological processing sequences are possible. However, skipping of work stations remains possible.

4.2.2. Temporal Organizational Principle of Internal Transport. The temporal organizational principle of internal transport 


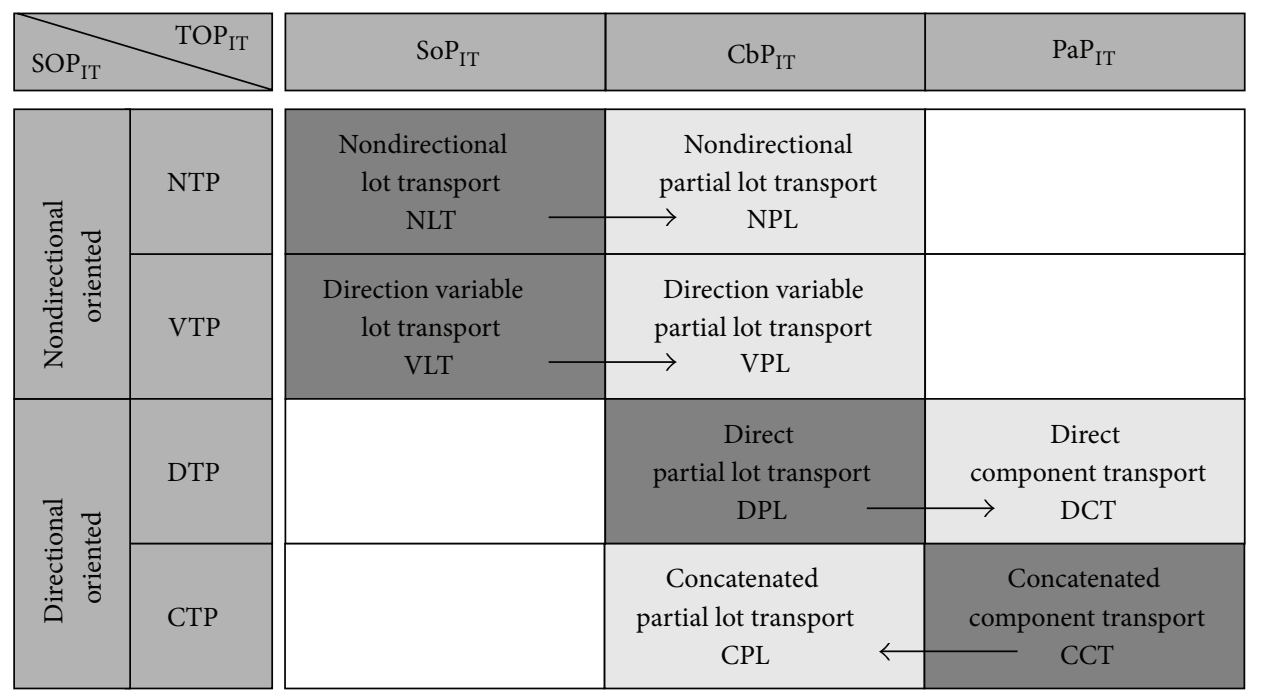

Primary organizational form of internal transport

Derivative organizational form of internal transport

No relevant possible combination

FIGURE 11: Organizational forms of internal transport (based on [23]).

defines method and timing of the movements of items from work station to work station in the manufacturing process. The respective cardinal variant of the temporal transport process relates to that [23]. In accordance with the temporal organizational principles of the main manufacturing processes, the internal transport process connects related production steps within the chosen division of labor scheme. Thus, temporal organizational principles of component manufacture and internal transport are a direct interface between main manufacturing and service processes [23].

4.2.3. Organizational Forms of Internal Transport. Organizational forms of internal transport consist of combinations of spatial organizational principles and temporal organizational principles [23]. From the presented spatial and temporal organizational principles twelve theoretically possible organizational forms of internal transport can be derived (see Figure 11). The analysis of the practicability of these twelve organizational forms leads to the distinction of (a) primary and (b) derivative organizational forms, but (c) also to some organizational forms without practical relevance, be it because they lack technical, technological, and/or economic efficiency $[23,98]$.

Primary organizational forms of internal transport primarily support transport operations as such and will be looked at in more detail [99]. Derivative organizational forms replace primary organizational forms in cases where transport problems have to be addressed under specific operational conditions in praxis, for example, splitting or overlapping of production lots or methods to enhance the transport utilization ratio [23]. The organizational forms of internal transport have, pending their respective spatial and temporal structures, varying continuity and flexibility potentials (see Figure 12).

Organizational forms of internal transport with high flexibility potential show tendentiously low continuity, whilst organizational forms with high continuity usually show low flexibility potential.

\section{Combinations of Organizational Solutions for Process Types}

The analysis and characteristic of requirement profiles of all process types and ability profiles of theoretically relevant organizational principles and forms are the basis to answer the question which organizational form fits best to which process type.

The assumption is that an efficient organization of a production process for each process type can only be achieved by a combination of coordinated organizational principles and forms of the respective main manufacturing processes and production support services. This theoretical approach will be investigated for the interaction of the organization of component manufacture and internal transport (acknowledging the fact though that this covers only a limited range of all operational options and combinations thereof).

Resulting selection and correlation issues have academic/theoretical as well as practical business relevance.

Two problems show the academic/theoretical relevance.

(i) The first problem is the correlation between (a) theoretically relevant options of classical organizational principles and organizational forms of component manufacture and (b) the respective process types together with their requirement profiles. 


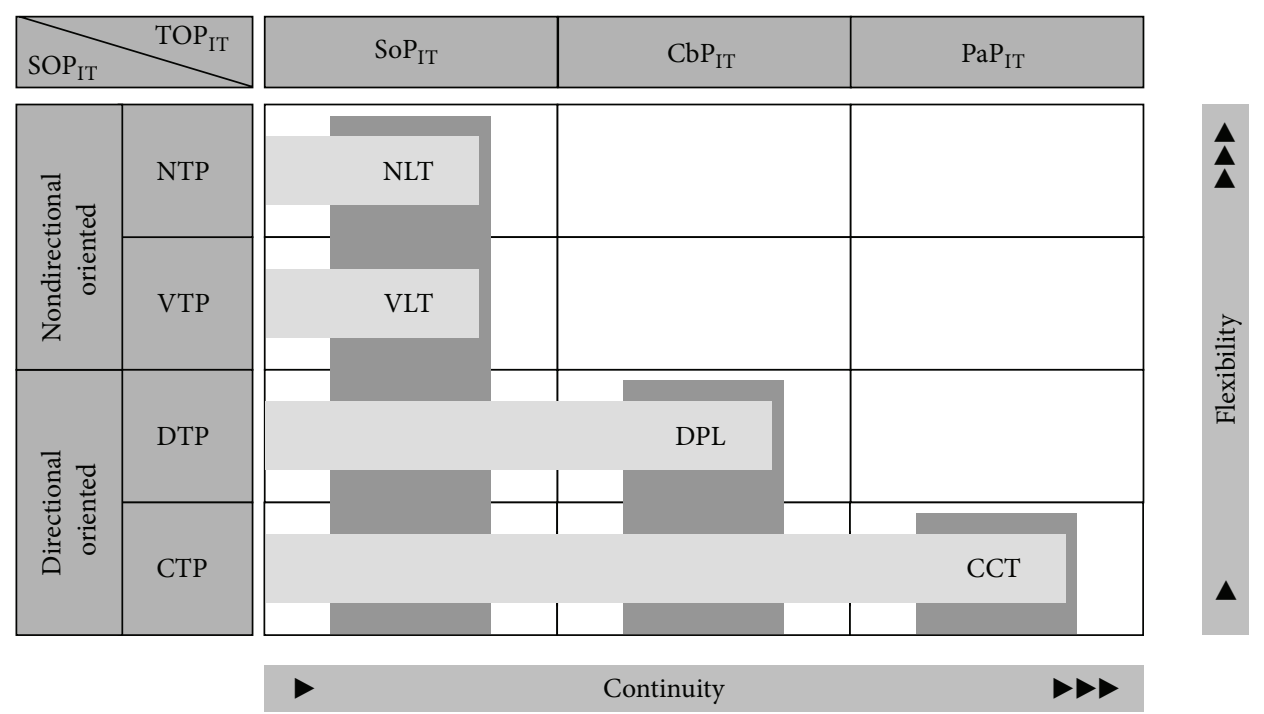

FIGURE 12: Potentials in flexibility and continuity of organizational forms of the internal transport ([23] based on [27]).

(ii) The second problem is the correlation between (a) organizational principles and forms of internal transport and (b) classical and/or modern organizational principles and organizational forms of component manufacture.

An understanding of the practical business relevance requires a comparison between the reference (target) organizational settings of a company with the existing organizational settings which then leads to a new organizational design of a reengineered (reorganized) solution.

\subsection{Linking Process Types and Corresponding Organizational} Forms of Component Manufacture. Each identified process type has its specific requirement profile which needs to be aligned with the respective ability profile of the organizational setting. Analysis is required to determine which organizational principles and forms of component manufacture embrace ability profiles that-from an efficiency perspective-best fit the respective requirement profiles. In support of such analysis the following decision algorithm has been developed. It starts with the specifics of the production program which subsequently determines the process type (see Figure 13(a)).

The specific requirement profiles (see Table 2 ) are defined by (a) the similarity of components within their component classes, (b) the manufacturing methods that are used for manufacturing, (c) the required direction of the production flow, (d) the capacity utilization potentials of particular assets, and (e) the proportionality of time requirements for working cycles. All this leads to distinctive typical guiding principles:

(i) flexibility through procedure specialization;

(ii) flexibility through object specialization;

(iii) continuity through object specialization;

(iv) distinct continuity through object specialization.
In furtherance to this, three additional results of relevance are (a) options of technological processing sequences, (b) corresponding spatial and temporal organizational principles, and (c) organizational forms of component manufacture based on combinations of (b) (see Figure 13(b)).

The scheme consolidates process types and their requirement profiles with classical organizational forms of component manufacture which are inclusive of aligned and suitable ability profiles.

Specifics regarding single user manufacturing (and machining center) [22] and series production [29] should not be discussed at this point.

Classical organizational forms and related modern organizational forms follow identical spatial and temporal organizational principles and thus a separate analysis of the correlation of process types and modern organizational forms of component manufacture is not needed. The attribution of modern organizational forms in the algorithm (see Figure 13(b)) follows this principle.

5.2. Linking Organizational Principles and Forms of Internal Transport and Corresponding Component Manufacture, Respectively. The assignment of organizational forms of the main manufacturing process "component manufacture" to corresponding process types is a primary decision whilst the selection and assignment of organizational forms of production support services-in this case internal transportwith respect to the organizational forms of component manufacture is a secondary decision.

Spatial organizational principles of component manufacture determine the spatial arrangement of all work stations which need to be covered by internal transport. Temporal organizational principles of component manufacture determine the way of passing on work items from work station to work station in accordance with the technological processing sequence. Temporal organizational principles of internal transport determine the operationalization of transports. 


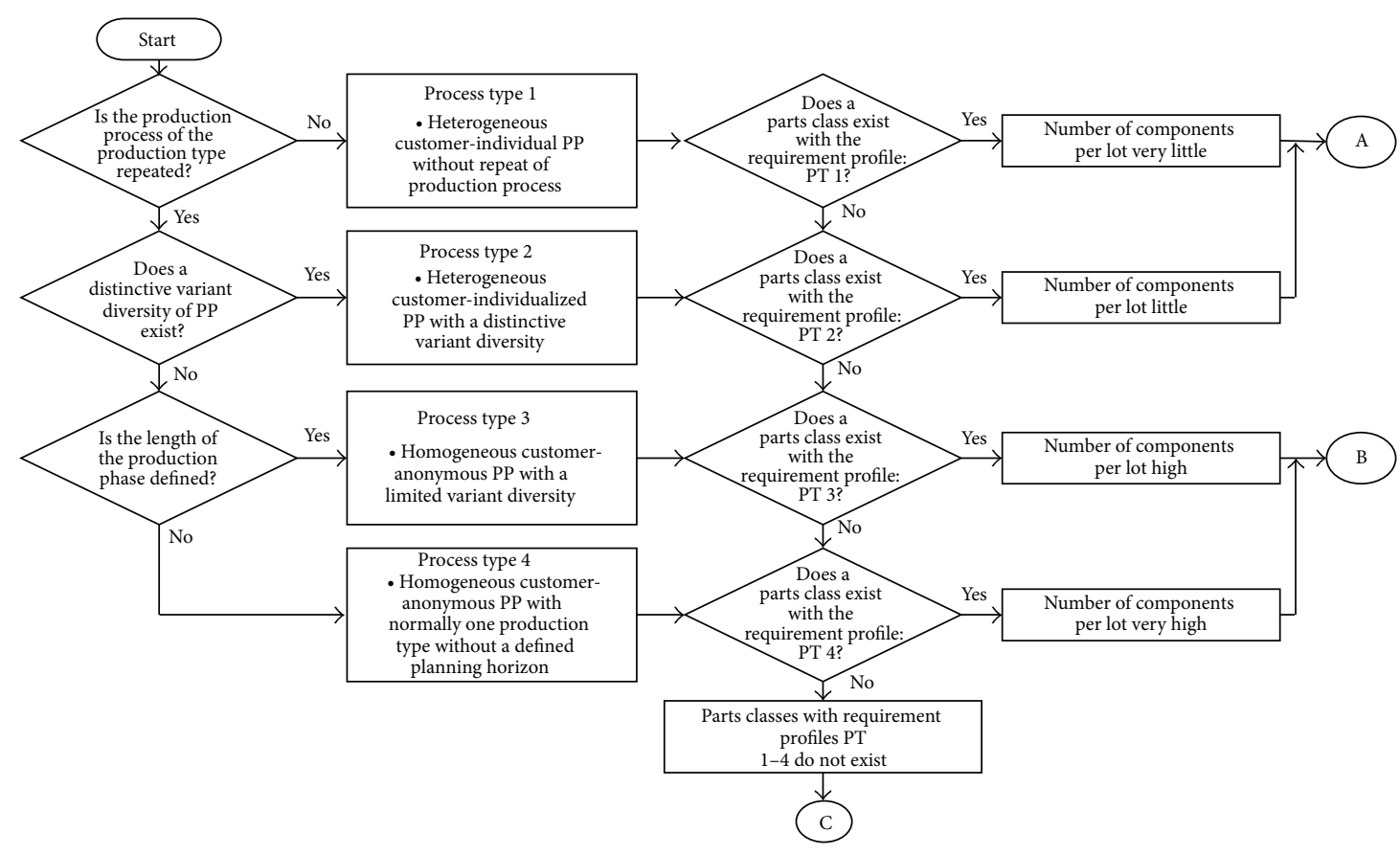

PP Production program

PT Process type

(a)

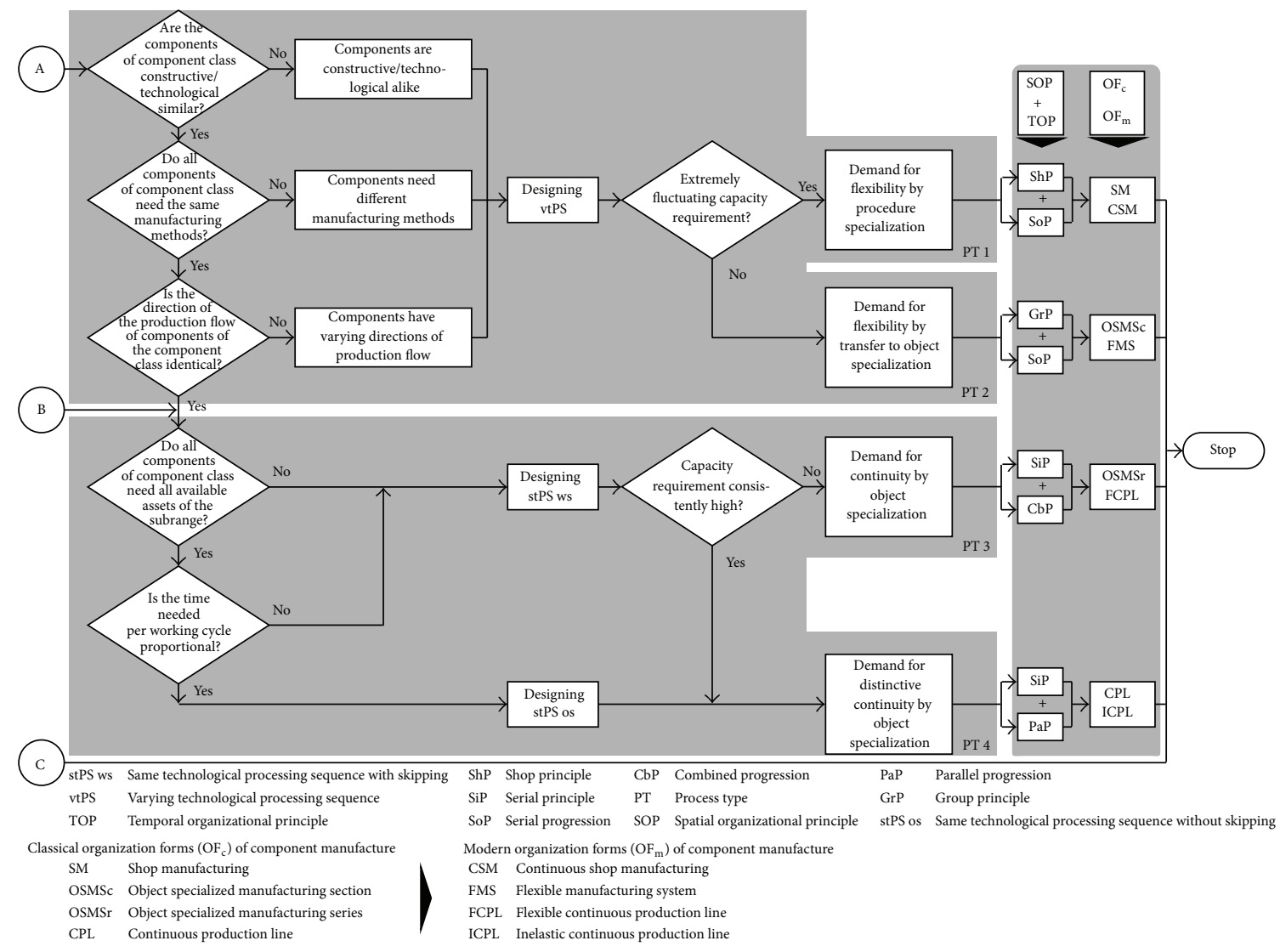

(b)

FIGURE 13: (a) Algorithm to link process types and organizational principles and forms of component manufacture (part 1). (b) Algorithm to link process types and organizational principles and forms of component manufacture (part 2). 
It can be also concluded that temporal organizational principles of component manufacture and those of internal transport are in this context identical and can be equally applied for organizational purposes.

Each organizational form of component manufacture has its inherent organizational principle. Taking into consideration the applied technological processing sequence, a coherent analysis supports the determination which spatial organizational principle is best suitable to be applied for the respective task (or-with an equal result-which temporal organizational principle of internal transport is identical with the temporal organizational principle of component manufacture).

A combination of the identified spatial and temporal organizational principles of internal transport determines the organizational form of internal transport. Subsequently, this aspect of organization has to be then combined with the organizational form of component manufacture.

All organizational forms of component manufacture have the following correlations with organizational forms of internal transport (see Figure 14).

Combinations related to single user manufacturing or the machining center and transport organization have been excluded since they are irrelevant due to lack of transport requirements.

5.3. Organizational Alignment. Based on the marketing and production programs, the need for task splitting makes subprocesses necessary in order to address specific subtasks. These subtasks have, pending the relevant process type, requirement profiles that can also be understood as a task setting for the design of production organization. Hence, process type-oriented combined organizational solutions have to be found that are best suited to integrate ability profiles with requirement profiles.

Figure 15 summarizes requirement profiles of the four process types mentioned above. It also displays the combination variants of organizing component manufacture and internal transport, each with their ability profiles and their specific relevance for the corresponding process type.

To illustrate the complexity of combined organizational solutions a multilevel model has been developed in which all relevant organizational principles and organizational forms of the main manufacturing processes and also production support services can be classified in accordance with their corresponding specific process type (see Figure 16).

Process types are the starting point. They are classified by (partly conflicting) dimensions of quantity, variant diversity, continuity, and flexibility. Moreover, they point at the requirement profiles which need to be factored into the organizational approach. In addition, they also dictate the conditions of the design of the organizational setting. They are finally positioned into various levels after further differentiations were made between component manufacture and internal transport, all based on relevant organizational principles and forms. Figure 16 illustrates the interdependency in a graphical form.
The vertical projections point out those combinations that, from a component manufacture and internal transport perspective, represent the most efficient solution of production organization. Combinations which deviate from the vertical projection are possible and under certain circumstances they may provide for a viable option [101]. However, economic losses have to be expected (also discussed for FMS by Sujono and Lashkari [102]) because in such cases requirement profiles are not congruent with the respective ability profiles.

Going beyond the main focus of this paper (organization of component manufacture and internal transport) combined solutions can be inclusive of additional organizational fields such as (a) the main manufacturing process assembly [26] and (b) the production support services internal storage [23], maintenance [27, 104], and information management [24] as well as others as deemed necessary.

The vertical projections of combinations are not only of theoretical relevance but should also guide practical organizational solutions. Corporate practice-more often than not-deviates from such theoretically ideal solutions which give ground for reengineering (reorganizing) approaches [105-107].

Schreyögg and Sydow [108] have examined in a much broader sense the general implications for organization theory with regard to what we believe to some extent narrows down to the fundamental struggle between organizational stability and flexibility in changing business environments triggering adaptation measures and the resulting dilemmas in many different ways from there. In principle, they advocate for " $[\cdots]$ concern for countervailing processes and the mastering of contradictory or even paradoxical requirements in organizations $[\cdots]$ " [108]. In furtherance to this, they believe that "This refocusing would boil down to the need to build a new process-based organizational theory, which elaborates on the contradictory requirements systematically as well as mastering them." [108] This paper zooms very specifically on production organization processes and it is believed that, even on this, by comparison with Schreyögg and Sydow, microlevel, some of the fundamental thoughts they have laid out resonate with what our organizational frameworks are able to provide.

\section{Implications and Directions for Future Research}

6.1. Profile Comparison-Reengineering Approach. Economic survival and sustainable competitiveness of a company require constant monitoring and reviews of production processes (and subprocesses) and their respective organizational forms. The ability to adapt to changing production tasks with optimum economic efficiency is the reference.

Such a review is based on profile comparison. Two aspects are compared: (a) organizational requirement profiles of component classes' production and their respective subprocesses and (b) organizational ability profiles of all relevant 

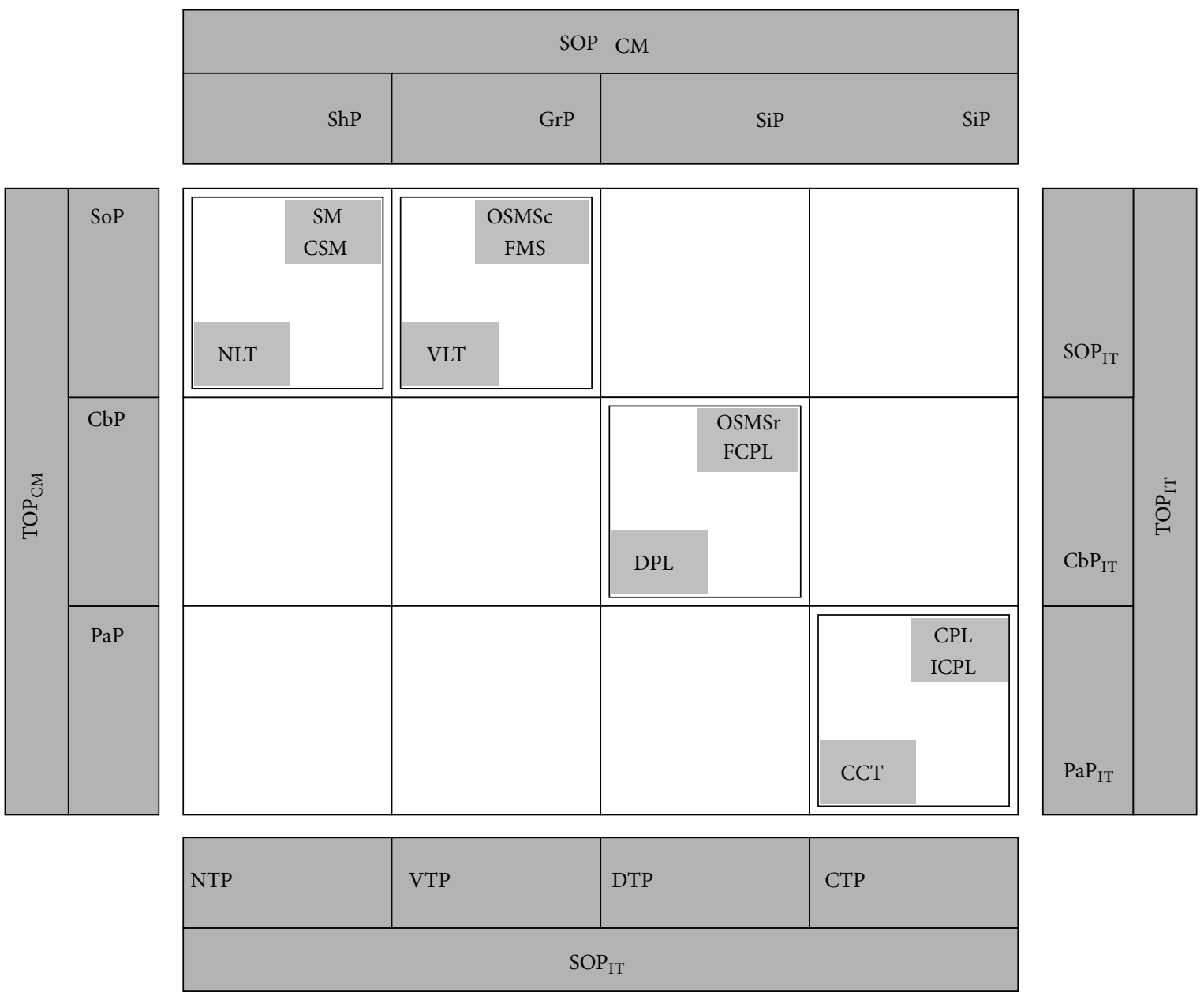

Classical organization forms $\left(\mathrm{OF}_{\mathrm{c}}\right)$ of component manufacture

CPL Continuous production line

OSMSc Object specialized manufacturing section

OSMSr Object specialized manufacturing series

SM Shop manufacturing

Modern organization forms $\left(\mathrm{OF}_{\mathrm{m}}\right)$ of component manufacture

CSM Continuous shop manufacturing

FCPL Flexible continuous production line

FMS Flexible manufacturing system

ICPL Inelastic continuous production line

Organizational forms of internal transport

CCT Concatenated component transport

DPL Direct partial lot transport

NLT Nondirectional lot transport

VLT Direction variable lot transport
SOP Spatial organizational principle

CTP Concatenated transport principle

DTP Direction transport principle

GrP Group principle

NTP Nondirectional transport principle

ShP Shop principle

SiP Serial principle

VTP Direction variable transport principle

TOP Temporal organizational principle

CbP Combined progression

$\mathrm{PaP}$ Parallel progression

SoP Serial progression

$\mathrm{CM}$ Component manufacture

IT Internal transport

FIGURE 14: Interdependencies of organizational principles and forms of component manufacture and internal transport (based on [21, 23, 25, $29,99,100])$.

subprocesses of a company. It is then diagnosed whether or not the existing subprocesses and their corresponding organizational solutions are efficiently able to support changing production programs and resulting new requirements for production organization.
Profile comparison is particularly relevant, because

(i) existing organizational settings and their underlying organizational principles and forms have been designed in accordance with their ability profiles and 


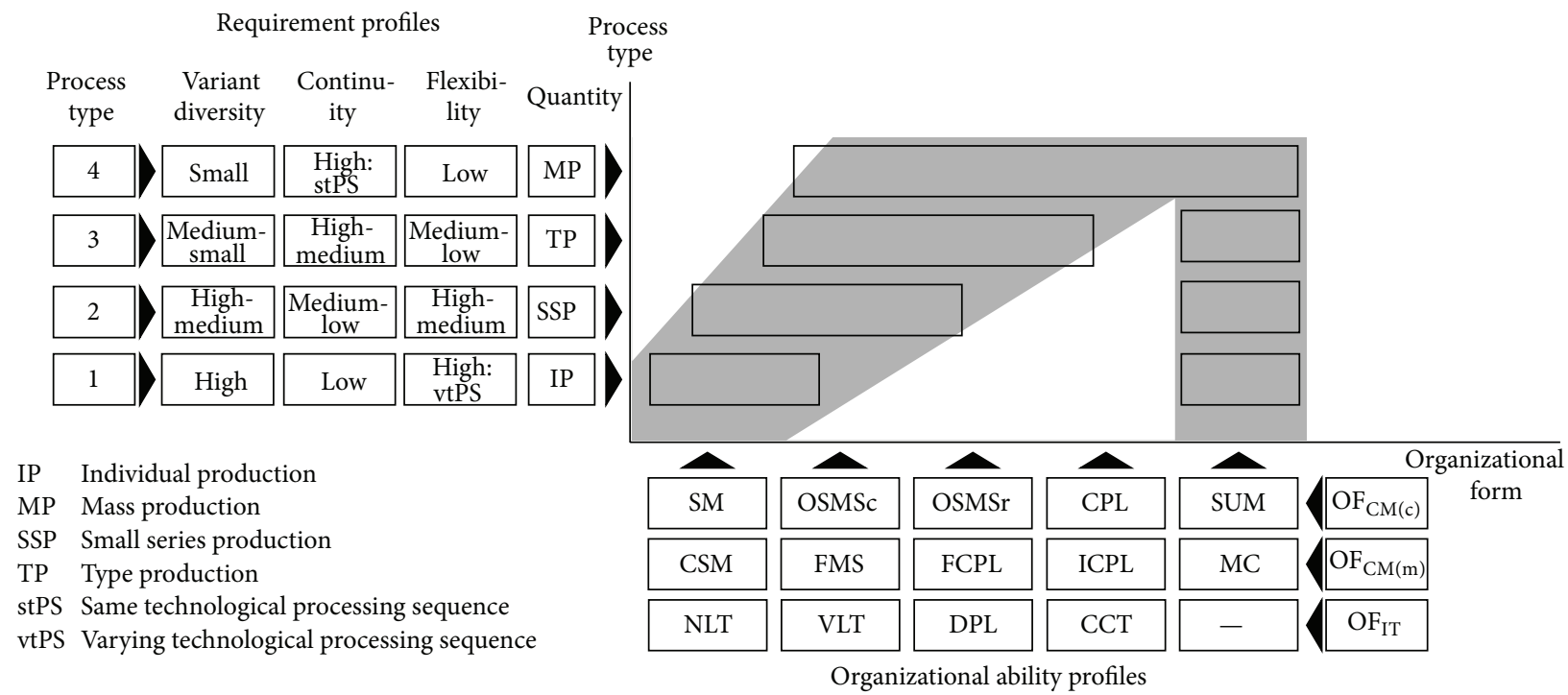

FIGURE 15: Connection between requirement profiles of process types and organizational forms (based on [22]).

in support of the respective requirement profiles, which were based on a former (now outdated) production program;

(ii) existing organizational settings with their specific ability profiles had not been optimally adjusted to the respective requirement profiles;

(iii) it cannot be expected that existing organizational settings with their ability profiles optimally fit in with the requirement profiles of production tasks that are the result of dynamic program developments;

(iv) changing production programs can lead to the fact that for new component classes with their respective requirement profiles make the creation of new subprocesses with appropriate ability profiles of the organizational setting necessary;

(v) after program changes, production tasks become irrelevant for existing subprocesses and are not replaced by new production tasks.

As a result of profile comparison, relevant reengineering tasks are identified in support of a new organizational setting. The aim is that measures are taken which, as much as possible, adapt ability profiles of an organizational setting to requirement profiles. This in turn requires general changes of the existing organizational setting.

Figure 17 highlights the algorithm of profile comparison which leads to the identification of the reengineering remit in terms of production related organizational settings.

Four principle resulting scenarios can be expected.

Variant 1. Identification of remaining gratuitous subprocesses after new program development. Reengineering shall eliminate such subprocesses. It requires disinvesting and discharging labor in the affected areas.

Variant 2. Absence of an appropriate subprocess for the production of a component class in the company. Reengineering shall bring out and organize a new subprocess in a way that it meets the requirement profile of the component class in question.

Variant 3. Projected and existing subprocesses match and equally so the respective requirement and ability profiles of the organizational setting of production. In this case, no adaptations through reengineering are needed. In some instances level adaptations of technological principles, a deeper integration of production support services, and improved qualifications of the work force should be considered.

Variant 4. Projected and existing subprocesses match, but requirement profiles and ability profiles of the organizational setting are not optimally attuned. This results in reengineering tasks related to changes of spatial and temporal organizational principles.

Selected reengineering design options of identified variants are shown in more depth in Figure 18. Usually such options are closely linked with complex solutions related to asset management (but also material management and human resources), and they require various strategy options for asset modernization [101, 109].

Through profile comparison, identified resulting variants and therefrom deducted design options of reengineering praxis-oriented solutions can be developed.

In as much as it is believed that fine tuning production process does contribute to the overall success of a company, we are also absolutely clear about the fact that operational measures at this (micro-) organizational level must feed into 


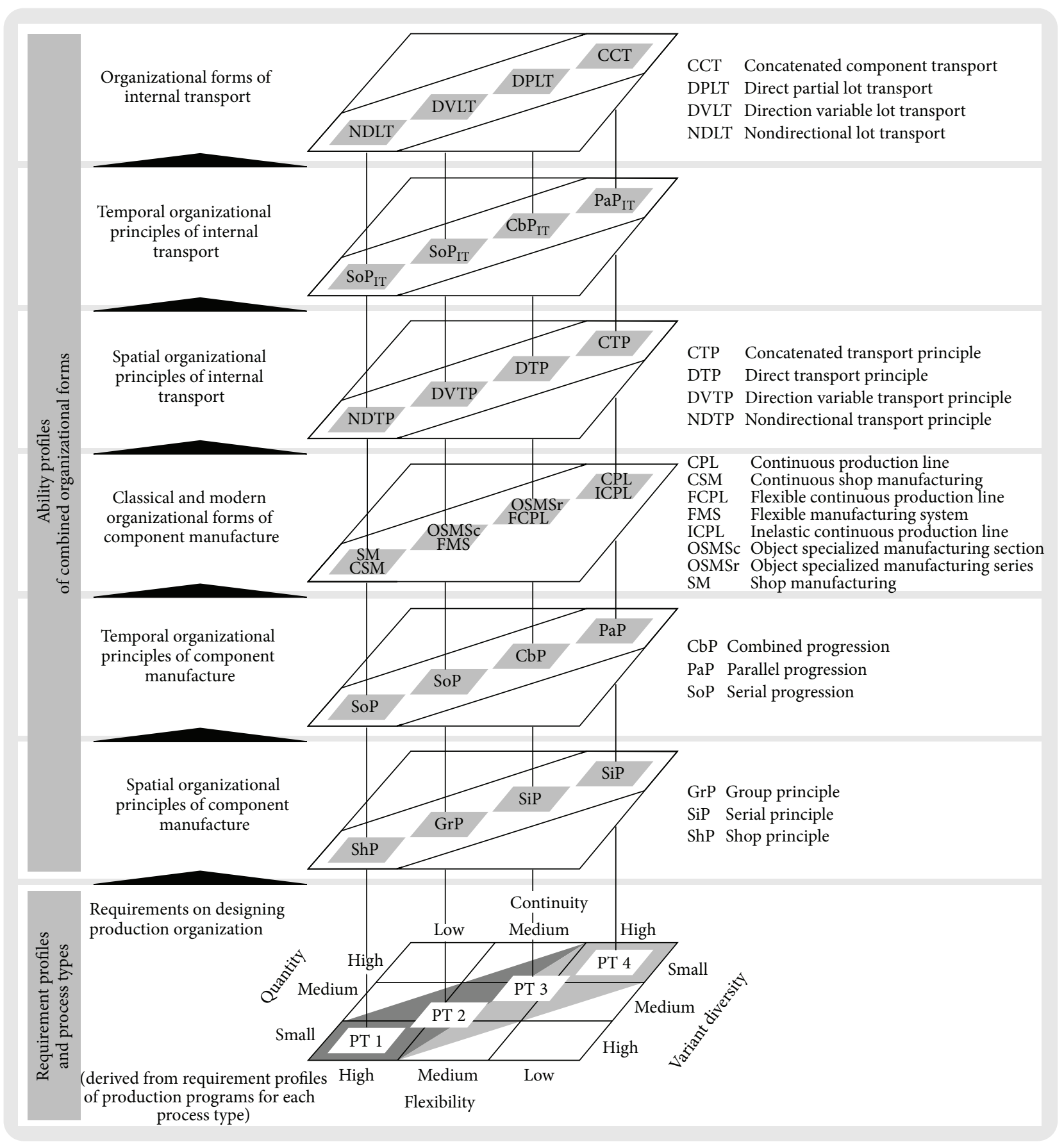

FIGURE 16: Multilevel organizational alignment model (based on [23, 28, 29, 103]).

to a much wider, and less technical, strategic approach to secure strategic success of a company. In furtherance to this, Mc Kinlay and Starkey state that "in market situations where the flexibility and responsiveness of work organizations is crucial to competitive advantage, successful change strategies cannot be premised on the simplicities of the structurestrategy paradigm.” [110].

6.2. Suggestions for Future Research. Our multilevel organizational alignment model for production process types brings together a multitude of principle factors, related interdependencies, and combinations thereof in order to generate theoretical "raw material" - Step 1-leading to conceptual options for organizational solutions (DMS, RMS, FMS, AMS)Step 2-which can define practical applications of real organizational configurations with the respective hard- and software-Step 3. Our findings suggest that further progress in designing manufacture systems of whatever nature may benefit from knowledge relatable to Step 1. We zoomed into the very basics of production subprocesses of component 


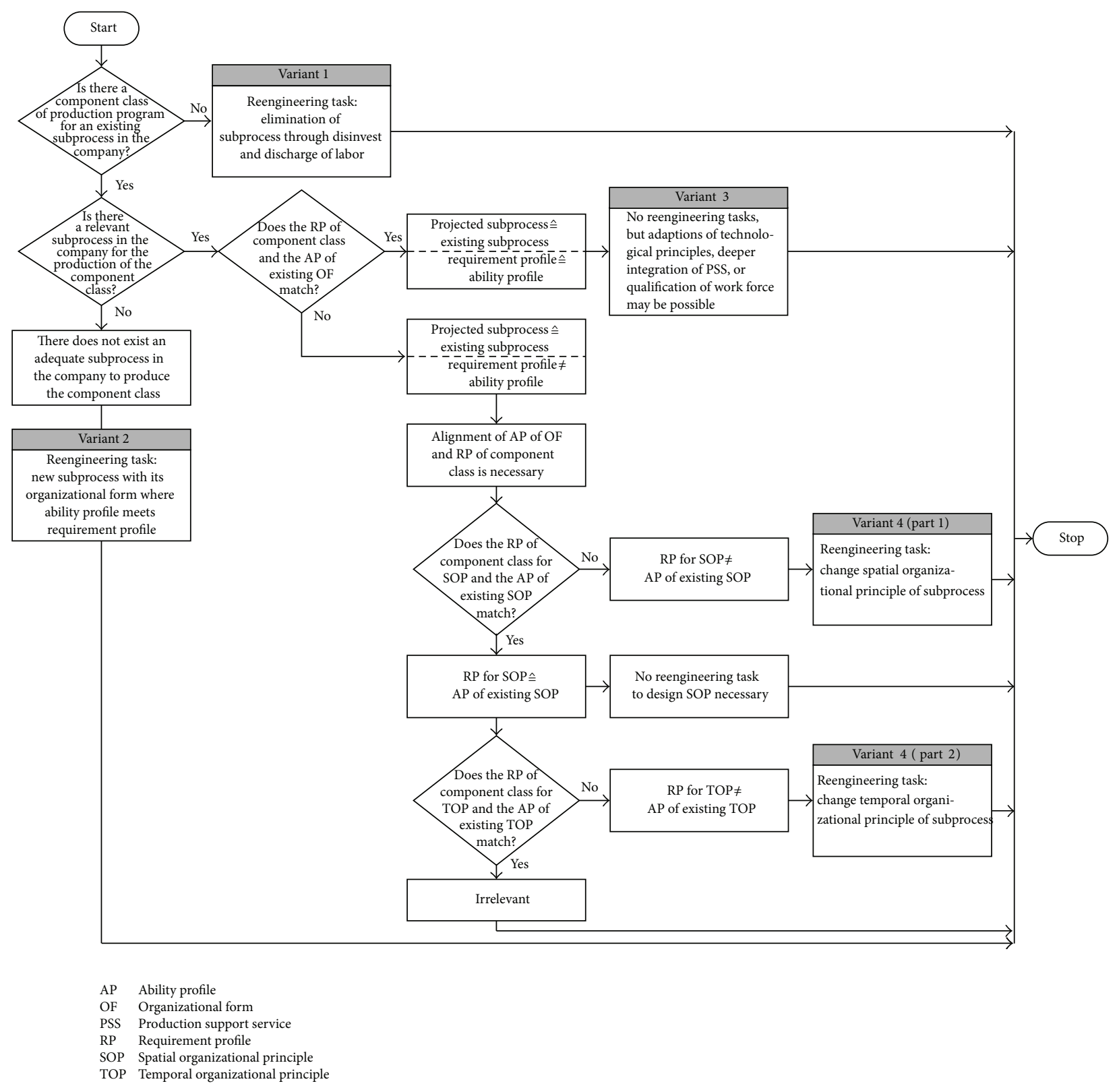

FIGURE 17: Reengineering tasks in organizational settings of production.

manufacture (as part of the main manufacturing processes) and internal transport (as part of the production support services) with the respective requirement profiles and four correlating production process types. When the requirements for production processes change, organizational gaps in response to such changes in production demands are system-wise closed by corresponding organizational ability profiles that are based on further categorized organizational principles (e.g., spatial, temporal, and technical) and forms (e.g., classical, modern, primary, and derivative). There are three directions into which what has been presented can be further develop and/or additional research is required.

First, on the current system level, the model is complete and has the ability to provide raw material for organizational solutions as described above. Thus, it can be replicated into other closely linked fields of principle organizational relevance, for example, internal storage, maintenance, information system, and quality management.

Second, by combining the various organizational models, an "all-inclusive" multilevel organizational alignment model should be developed which would provide for even more complex solutions for organizational problems. The challenge will be to integrate the specific ability profiles of each segment without compromising the overall validity and practical feasibility of such an advanced model.

Third, the predominantly theoretical approach of our research-which at its core aims at providing a better understanding of fundamental principles of production 


\begin{tabular}{|c|c|c|c|c|}
\hline $\begin{array}{l}\text { Results of } \\
\text { profile } \\
\text { comparison }\end{array}$ & Variant 1 & Variant 2 & Variant 3 & Variant 4 \\
\hline $\begin{array}{l}\text { Design } \\
\text { options of } \\
\text { reengineering }\end{array}$ & $\begin{array}{l}\text { (A) Cooperation with } \\
\text { third party } \\
\text { (B) Disinvestment of } \\
\text { the unuseable } \\
\text { subprocess } \\
\text { - Discharge or transfer } \\
\text { of labor } \\
\text { - Selection or transfer } \\
\text { of assets } \\
\text { (C) Strategy: } \\
\text { incompletely } \\
\text { reduced plant } \\
\text { renewal }\end{array}$ & $\begin{array}{l}\text { (A) Placement of } \\
\text { production tasks in } \\
\text { other existing } \\
\text { subprocesses with high } \\
\text { flexibility } \\
\text { - Capacity adjustment } \\
\text { - Improvement of } \\
\text { asset's condition } \\
\text { (B) Outsourcing of } \\
\text { component class } \\
\text { (C) Organization of a } \\
\text { new subprocess: } \\
\text { - Investment in assets } \\
\text { - Qualification of the } \\
\text { work force } \\
\text { - Designing spatial, } \\
\text { temporal, and/or } \\
\text { technological } \\
\text { organizational } \\
\text { principles } \\
\text { - Designing } \\
\text { organizational forms } \\
\text { (D) Strategy: } \\
\text { completely } \\
\text { advanced plant } \\
\text { renewal }\end{array}$ & $\begin{array}{l}\text { (A) No measures to } \\
\text { design organizational } \\
\text { principles and forms } \\
\text { of the main manufac- } \\
\text { turing processes } \\
\text { Alternatively } \\
\text { (B) Improvement of } \\
\text { combined organiza- } \\
\text { tional solutions } \\
\text { (main manufacturing } \\
\text { processes and } \\
\text { production support } \\
\text { services) } \\
\text { (C) Rationalization } \\
\text { measures } \\
\text { - Qualification of the } \\
\text { work force } \\
\text { - Integration of } \\
\text { technological } \\
\text { organizational } \\
\text { principles } \\
\text { - Ensuring available } \\
\text { capacity } \\
\text { (D) Strategy: } \\
\text { completely simple } \\
\text { plant renewal }\end{array}$ & $\begin{array}{l}\text { (A) Rationalization through } \\
\text { reengineering } \\
\text { - Change towards } \\
\text { object specialization } \\
\text { SOP: SiP } \\
\text { TOP: CbP, PaP } \\
\text { TOP: changing } \\
\text { levels of technical } \\
\text { sophistications } \\
\text { - Change towards } \\
\text { procedure specia- } \\
\text { lization } \\
\text { SOP: ShP, GrP } \\
\text { TOP: SoP } \\
\text { TOP: changing } \\
\text { levels of technical } \\
\text { sophistications } \\
\text { (B) Consequences for } \\
\text { asset management } \\
\text { - Old OP, OF- } \\
\text { strategy: } \\
\text { incompletely } \\
\text { reduced plant } \\
\text { renewal } \\
\text { - New OP, OF- } \\
\text { strategy: } \\
\text { completely } \\
\text { advanced plant } \\
\text { renewal }\end{array}$ \\
\hline
\end{tabular}

FIGURE 18: Selected design options for resulting reengineering variants.

organization-needs to be closer linked to and further tested against the current production organizational system development theory and praxis (e.g., DMS, FMS, CMS, etc.).

\section{Summary}

The corporate world is constantly under pressure to adapt to manifold new challenges. Finding optimum organizational solutions is a vital aspect for any company to maintain and extend its competitiveness. Methodology-wise, deductive thinking as well as theoretical conceptualization has been chosen as a starting point to systematically refine pertinent terms, principles, processes, interdependencies, and combinations of organizationally relevant factors for efficient production.

One factor of fundamental importance is an in-depth analytical understanding of differentiated requirement profiles of production programs and corresponding process types. We have systemized such requirement profiles and linked them to four corresponding process types.

Building on this and using the examples of "component manufacture" and its related production support service "internal transport," resulting organizational options together with their respective ability profiles are laid out. Potential organizational options and their applicability are further analyzed in light of production programs requirements and their respective manufacturing process/organization. A complex multilevel organizational alignment model (see Figure 16) brings together through what we call "organizational alignment" all interdependencies and correlations between process types related organizational principles/forms, predefined requirements, and shows resulting (theoretically) optimized organizational solutions.

In furtherance to this, comparative analysis of organizational requirement and ability profiles lead to an efficiencybased choice of organizational solutions. The production aspects "component manufacture" and "internal transport" have been chosen as examples to explain the underlying theory. Reengineering approaches were systematized and subsequently developed towards (potentially) resulting organizational adaptations.

Decisions for organizational solutions in relation to requirement profiles must be informed by theoretical analysis as well as feasibility considerations concerning organizational principles and organizational forms of manufacturing subprocesses within the parameters of their respective ability profiles.

\section{Conflict of Interests}

The authors declare that there is no conflict of interests regarding the publication of this paper. 


\section{References}

[1] E. Frese, M. Graumann, and L. Theuvsen, Grundlagen der Organisation: Entscheidungsorientiertes Konzept der Organisationsgestaltung, Gabler, Wiesbaden, Germany, 2012.

[2] A. Scheibler, Unternehmungs-Organisation. Lehrbuch für Studium und Praxis, Gabler, Wiesbaden, Germany, 1974.

[3] E. Grochla, Unternehmungsorganisation, Westdeutscher, Opladen, Germany, 1981.

[4] F. X. Bea and M. Schweitzer, Allgemeine Betriebswirtschaftslehre. Band 2: Führung, UVK Verlagsgesellschaft mbH, Konstanz, Germany, 2011.

[5] K. Olfert, Organisation, Kiehl, Ludwigshafen, Germany, 2009.

[6] E. Kosiol, Organisation der Unternehmung, Gabler, Wiesbaden, Germany, 1976.

[7] G. Schreyögg, Organisation: Grundlagen Moderner Organisationsgestaltung, Gabler, Wiesbaden, Germany, 2008.

[8] W. Mayrhofer, M. Meyer, and S. Titscher, Eds., Praxis der Organisationsanalyse: Anwendungsfelder und Methoden, Facultas, Vienna, Austria, 2010.

[9] M. Schweitzer, Industriebetriebslehre. Das Wirtschaften in Industrieunternehmungen, Vahlen, München, Germany, 1990.

[10] E. Gutenberg, Grundlagen der Betriebswirtschaftslehre, Band 1: Die Produktion, Springer, Berlin, Germany, 1957.

[11] P. A. Steinbuch, Organisation, Kiehl, Ludwigshafenm, Germany, 1990.

[12] S. P. Robbins, Organisation der Unternehmung, Pearson Studium, München, Germany, 2001.

[13] Y. Koren, U. Heisel, F. Jovane et al., "Reconfigurable manufacturing systems," CIRP Annals-Manufacturing Technology, vol. 48, no. 2, pp. 527-540, 1999.

[14] C. Zopff, Informationsmanagement in Kleinen und Mittelgroßen Unternehmen (KMU): Unternehmenstypologie und Gestaltungsansatz am Beispiel des Auftragsdurchlaufs der Metallverarbeitenden Industrie, Shaker, Aachen, Germany, 2005.

[15] T. Cox Jr., "Toward the measurement of manufacturing flexibility," Production and Inventory Management Journal, vol. 30, no. 1, pp. 68-72, 1989.

[16] L. L. Koste and M. K. Malhotra, "Theoretical framework for analyzing the dimensions of manufacturing flexibility," Journal of Operations Management, vol. 18, no. 1, pp. 75-93, 1999.

[17] F. A. G. Kempf, Flexibilitätsorientierte ProduktionssystemeModulare Gestaltung, Einführung und Nutzung, Produktionstechnische Berichte aus dem FBK, Band 07, Universität Kaiserslautern, Kaiserslautern, Germany, 2010.

[18] D. Gupta and J. A. Buzacott, "A framework for understanding flexibility of manufacturing systems," Journal of Manufacturing Systems, vol. 8, no. 2, pp. 89-97, 1989.

[19] O. S. Yilmaz and R. P. Davis, "Flexible manufacturing systems. Characteristics and assessment," Engineering Management International, vol. 4, no. 3, pp. 209-212, 1987.

[20] H. A. ElMaraghy, "Flexible and reconfigurable manufacturing systems paradigms," International Journal of Flexible Manufacturing Systems, vol. 17, no. 4, pp. 261-276, 2005.

[21] T. Nebl, Produktionswirtschaft, Oldenbourg, München, Germany, 2011.

[22] T. Nebl, Production Management, Oldenbourg, München, Germany, 2002.
[23] R. Drews, Organisationsformen der Produktionslogistik: Konzeptionelle Gestaltung und Analyse der Wechselbeziehungen zu den Organisationsformen der Teilefertigung, Shaker, Aachen, Germany, 2006.

[24] G. Grytsch, Organisationsformen des Informationsmanagements. Theoretische Grundlagen, Organisationsprinzipien und Gestaltungsansätze, Shaker, Aachen, Germany, 2011.

[25] K. Heinsberg, Systematisierung der theoretischen Grundlagen einer wirtschaftlichen Lagerorganisation, Shaker, Aachen, Germany, 2004.

[26] T. Petersen, Organisationsformen der Montage, Shaker, Aachen, Germany, 2005.

[27] P. Runge, Die Gestaltung der Organisationsformen der Instandhaltung unter besonderer Beachtung ihrer Abhängigkeit von den Organisationsformen der Telefertigung, Shaker, Aachen, Germany, 2000.

[28] K. Silberbach, Der Einfluß Organisatorischer und Technischer Gestaltungskriterien auf die Bildung von Organisationsformen der Teilefertigung, Shaker, Aachen, Germany, 1997.

[29] I. Teichner, Organisation der kundenindividuellen Massenproduktion, Shaker, Aachen, Germany, 2012.

[30] M. E. Porter, Competitive Strategy: Techniques for Analysing Industries and Competitors, The Free Press, New York, NY, USA, 1980.

[31] M. T. Sweeney, "Towards a unified theory of strategic manufacturing management," International Journal of Operations \& Production Management, vol. 11, no. 8, pp. 6-22, 1991.

[32] T. Nebi, "Organisationsformen der Teilefertigung," ZWF Zeitschrift fuer Wirtschaftlichen Fabrikbetrieb, vol. 102, no. 11, pp. 717-722, 2007.

[33] K. Kieliszek, Computer Aided Selling: Unternehmenstypologische Marktanalyse, Gabler, Wiesbaden, Germany, 1994.

[34] T. Nebl and A. Dikow, Produktivitätsmanagement: Theoretische Grundlagen, methodische Instrumentarien, Analyseergebnisse und Praxiserfahrungen zur Produktivitätssteigerung in Produzierenden Unternehmen, Hanser, München, Germany, 2004.

[35] C. Zopff and T. Nebl, "Information management for the realization of carrying out orders in small and mid size companies (KMU)," ZWF Zeitschrift für Wirtschaftlichen Fabrikbetrieb, vol. 101, no. 6, pp. 338-343, 2006.

[36] G. Schuh and V. Stich, Produktionsplanung und-Steuerung: Grundlagen der PPS, Springer, Berlin, Germany, 2012.

[37] H. Gienke, R. Kämpf, and R. Kämpf, Handbuch Produktion. Innovatives Produktionsmanagement: Organisation, Konzepte, Controlling, Hanser, Munich, Germany, 2007.

[38] C.-G. Grundig, Fabrikplanung: Planungssystematik-Methode-Anwendungen, Hanser, München, Germany, 2009.

[39] K.-P. Kistner and M. Steven, Produktionsplanung, Physica, Heidelberg, Germany, 2001.

[40] R. Wenzel, G. Fischer, G. Metze, and P. Nieß, Industriebetriebslehre. Das Management des Produktionsbetriebs, Leipzig, München, Germany, 2001.

[41] G. Zäpfel, Taktisches Produktions-Management, Oldenbourg, München, Germany, 2000.

[42] G. Schuh, Produktionsplanung und -Steuerung. Grundlagen, Gestaltung und Konzepte, Springer, Berlin, Germany, 2006.

[43] H.-J. Warnecke, Der Produktionsbetrieb 2. Produktion, Produktionssicherung, Springer, Berlin, Germany, 1995.

[44] S. Poenicke, Beurteilung und Auswahl alternativer Gestaltungsvarianten von Organisationsformen der Teilefertigung, Shaker, Aachen, Germany, 2000. 
[45] H. Schmigalla, Methoden zur Optimalen Maschinenanordnung, VEB Verlag Technik, Berlin, Germany, 1969.

[46] J. Neumann, S. Hasselbach, H. Klinger, G. Richter, and W. H. Sieber, Ökonomie der Produktionsdurchführung, Die Wirtschaft, Berlin, Germany, 1984.

[47] H. Arnold, H. Borchert, and J. Schmidt, Der Produktionsprozeß im Industriebetrieb, Die Wirtschaft, Berlin, Germany, 1975.

[48] H.-K. Reuter, Fertigungsformen im Maschinenbau: Ein Beitrag zur Systematisierung und Auswahl, Druck als Manuskript, Wismar, Germany, 1979.

[49] Y. Koren, S. J. Hu, and T. W. Weber, "Impact of manufacturing system configuration on performance," CIRP AnnalsManufacturing Technology, vol. 47, no. 1, pp. 369-370, 1998.

[50] A.-K. Schröder, Qualitätsmanagement in kleinen und mittleren Unternehmen (KMU)_Bedeutung von Techniken des Qualitätsmanagement für die Lösung von Qualitätsproblemen, Shaker, Aachen, Germany, 2006.

[51] G. Schmidt, CAM: Algorithmen und Decision Support für die Fertigungssteuerung, Springer, Berlin, Germany, 1989.

[52] P. S. Adler, "Managing flexible automation," California Management Review, vol. 30, no. 3, pp. 34-56, 1980.

[53] G. C. Cainarca, M. G. Colombo, and S. Mariotti, "An evolutionary pattern of innovation diffusion. The case of flexible automation," Research Policy, vol. 18, no. 2, pp. 59-86, 1989.

[54] G. K. Hutchinson and J. R. Holland, "The economic value of flexible automation," Journal of Manufacturing Systems, vol. 1, no. 2, pp. 215-228, 1982.

[55] F. Jovane, Y. Koren, and C. R. Boër, "Present and future of flexible automation: towards new paradigms," CIRP Annals: Manufacturing Technology, vol. 52, no. 2, pp. 543-560, 2003.

[56] R. Parthasarthy and S. P. Sethi, "The impact of flexible automation on business strategy and organizational structure," The Academy of Management Review, vol. 17, no. 1, pp. 86-111, 1992.

[57] J. D. Goldhar, "What flexible automation means to your business," Modern Material Handling, vol. 39, no. 7, pp. 63-65, 1984.

[58] R. Buitenhek, B. Baynat, and Y. Dallery, "Production capacity of flexible manufacturing systems with fixed production ratios," International Journal of Flexible Manufacturing Systems, vol. 14, no. 3, pp. 203-225, 2002.

[59] M. Kaighobadi and K. Venkatesh, "Flexible manufacturing systems: an overview," International Journal of Operations and Production Management, vol. 14, no. 4, pp. 26-49, 1994.

[60] M. G. Mehrabi, A. G. Ulsoy, and Y. Koren, "Reconfigurable manufacturing systems: key to future manufacturing," Journal of Intelligent Manufacturing, vol. 11, no. 4, pp. 403-419, 2000.

[61] M. G. Mehrabi, A. G. Ulsoy, Y. Koren, and P. Heytler, “Trends and perspectives in flexible and reconfigurable manufacturing systems," Journal of Intelligent Manufacturing, vol. 13, no. 2, pp. 135-146, 2002.

[62] M. R. Abdi and A. W. Labib, "A design strategy for reconfigurable manufacturing systems (RMSs) using analytical hierarchical process (AHP): a case study," International Journal of Production Research, vol. 41, no. 10, pp. 2273-2299, 2003.

[63] S. Nain and R. M. Belokar, "Restructuring of manufacturing process using matrix method: a case study," in Proceedings of the World Congress on Engineering and Computer Science, vol. 2, San Francisco, Calif, USA, October 2012.

[64] L. L. Berry and A. Parasuraman, Marketing Services: Competing through Quality, Maxwell Macmillan International, New York, NY, USA, 1991.
[65] H. Corsten and R. Gössinger, Dienstleistungsmanagement, Oldenbourg, München, Germany, 2007.

[66] S. Fließ, Dienstleistungsmanagement. Kundenintegration Gestalten und Steuern, Gabler, Wiesbaden, Germany, 2009.

[67] C. Grönroos, Service Management and Marketing, John Wiley \& Sons, Chichester, UK, 2007.

[68] R. F. Lusch and S. L. Vargo, The Service-Dominant Logic of Marketing, M. E. Sharpe, New York, NY, USA, 2006.

[69] R. Maleri and U. Frietzsche, Grundlagen der Dienstleistungsproduktion, Springer, Berlin, Germany, 2008.

[70] H. Meffert and M. Bruhn, Dienstleistungsmarketing. Grundlagen-Konzepte-Methoden, Gabler, Wiesbaden, Germany, 2009.

[71] A. Meyer, "Dienstleistungs-marketing," in Handbuch Dienstleistungs-Marketing, Band 1, A. Meyer, Ed., pp. 3-22, SchäfferPoeschel, Stuttgart, Germany, 1998.

[72] F. Scheuch, Dienstleistungsmarketing, Vahlen, Munich, Germany, 2002.

[73] V. A. Zeithaml, M. J. Bitner, and D. D. Gremler, Services Marketing, McGraw-Hill, Boston, Mass, USA, 2009.

[74] H. Albach, Dienstleistungen in der Modernen Industriegesellschaft, Beck, München, Germany, 1989.

[75] H. Albach, "Dienstleistungsunternehmen in Deutschland," Zeitschrift für Betriebswirtschaft, vol. 59, pp. 397-420, 1989.

[76] M. Bruhn, "Markteinführung von dienstleistungen-vom prototyp zum marktfähigen produkt," in Service EngineeringEntwicklung und Gestaltung innovativer Dienstleistungen, H.-J. Bullinger and A.-W. Scheer, Eds., pp. 227-248, Springer, Berlin, Germany, 2003.

[77] W. H. Engelhardt and M. Reckenfelderbäumer, "Industrielles service-management," in Markt- und ProduktmanagementDie Instrumente des Business-to-Business-Marketing, $\mathrm{M}$. Kleinaltenkamp, W. Plinke, F. Jacob, and A. Söllner, Eds., pp. 209-317, Gabler, Wiesbaden, Germany, 2006.

[78] C. Gill, Architektur für das Service Engineering zur Entwicklung von technischen Dienstleistungen, Shaker, Aachen, Germany, 2003.

[79] W. Gruhler, Dienstleistungsbestimmter Strukturwandel in Deutschen Industrieunternehmen, Deutscher Instituts, Köln, Germany, 1990.

[80] W. Gruhler, "Gesamtwirtschaftliche bedeutung und einzelwirtschaftlicher stellenwert industrieller dienstleistungen," in Industrielle Dienstleistungen, H. Simon, Ed., pp. 23-40, SchäfferPoeschel, Stuttgart, Germany, 1993.

[81] J. Kuster, Systembündelung technischer Dienstleistungen, Shaker, Aachen, Germany, 2004.

[82] S. M. Läbe and F. N. Stolpmann, "Dienst am Kunden total?" Absatzwirtschaft, vol. 36, pp. 22-34, 1993.

[83] V. Liestmann, Gestaltung von Dienstleistungsfamilien in Analogie zur Gestaltung von Produktfamilien im Maschinenbau, Shaker, Aachen, Germany, 2004.

[84] G. Neckermann and H. Wessels, "Dienstleistungsangebot des Maschinenbaus," Zeitschrift für Betriebswirtschaft, vol. 62, pp. 521-538, 1992.

[85] G. Schuh and G. Gudergan, "Innovationsfähigkeit industrieller dienstleistungen in organisationsformen jenseits der hierarchie: eine empirische analyse," in Forum Dienstleistungsmanagement-Wertschöpfungsprozesse bei Dienstleistungen, M. Bruhn and B. Stauss, Eds., pp. 192-214, Gabler, Wiesbaden, Germany, 2007. 
[86] W. Sihn, R. Proksch, and F. Lehmann, "Produktbegleitende Dienstleistungen unter der Lupe-Was Kunden wirklich wollen. Ergebnisse einer Studie des Fraunhofer Instituts für Produktionstechnik und Automatisierung," Service Today, vol. 14 , no. 6, pp. 38-40, 2000.

[87] H. Simon, "Industrielle dienstleistungen und wettbewerbsstrategie," in Industrielle Dienstleistungen, H. Simon, Ed., pp. 3-22, Schäffer-Poeschel, Stuttgart, Germany, 1993.

[88] B. Stauss, "Bedeutung und realisierungsgrad des total quality management im industriellen service," in Dienstleistungsmarketing-Eine Bestandsaufnahme, E. M. Thelen and G. B. Mairamhof, Eds., pp. 203-230, Peter Lang, Frankfurt, Germany, 1993.

[89] H. Wildemann, Die Modulare Fabrik-Kundennahe Produktion durch Fertigungssegmentierung, TCW Transfer-Centrum, Munich, Germany, 1988.

[90] T. L. Wilson and F. E. Smith, "Business services 1982-1992growth, industry characteristics, financial performance," Industrial Marketing Management, vol. 25, no. 2, pp. 163-171, 1996.

[91] J. A. Buzacott and D. D. Yao, "Flexible manufacturing systems: a review of analytical models," Management Science, vol. 32, no. 7, pp. 890-905, 1986.

[92] P. Karande and S. Chakraborty, "Material handling equipment selection using weighted utility additive theory," Journal of Industrial Engineering, vol. 2013, Article ID 268708, 9 pages, 2013.

[93] N. Thebud, Fertigungsnahe Industrielle Dienstleistungen: Rationalisierungspotenzial für die Produktionsorganisation in KMU, Shaker, Aachen, Germany, 2007.

[94] H. Wildemann, Anlagenproduktivität. Leitfaden zur Steigerung der Anlageneffizienz, TCW-Transfer-Centrum, München, Germany, 1997.

[95] M. Busch, "Synergetic factory planning project with an example of the automotive supplier industry," in Proceedings of the 6th German Symposium Factory Planning, Factories for the Global Competition, Ludwigsburg, Germany, 2005.

[96] H.-P. Wiendahl, H. A. ElMaraghy, P. Nyhuis et al., "Changeable manufacturing-classification, design and operation," CIRP Annals-Manufacturing Technology, vol. 56, no. 2, pp. 783-809, 2007.

[97] S. Chittratanawat and J. S. Noble, "An integrated approach for facility layout, P/D location and material handling system design," International Journal of Production Research, vol. 37, no. 3, pp. 683-706, 1999.

[98] R. Drews and T. Nebl, "Organisation des fertigungsnahen industriellen dienstleistungsprozesses innerbetrieblicher transport," Zeitschrift für Wirtschaftlichen Fabrikbetrieb, vol. 103, no. 3, pp. 133-139, 2008.

[99] R. Drews, "Die Organisationsformen der Produktionslogistik," in 50 Jahre produktionswirtschaftliche Forschung und Lehre, G. Albrecht, A.-K. Schröder, and I. Wegner, Eds., pp. 29-45, Festschrift, Oldenbourg, München, Germany, 2009.

[100] R. Drews and T. Nebl, "Organisation des fertigungsnahen industriellen Dienstleistungsprozesses innerbetriebliche Lagerung," Zeitschrift für Wirtschaftlichen Fabrikbetrieb, vol. 103, no. 1-2, pp. 31-36, 2008.

[101] T. Nebl and A.-K. Schroeder, "Understanding the interdependencies of quality problems and productivity," The TQM Journal, vol. 23, no. 5, pp. 480-495, 2011.

[102] S. Sujono and R. S. Lashkari, "A multi-objective model of operation allocation and material handling system selection in
FMS design," International Journal of Production Economics, vol. 105, no. 1, pp. 116-133, 2007.

[103] T. Nebl and I. Teichner, "Einflüsse der produktionsorganisation auf die produktivität von unternehmen: am beispiel der kundenindividuellen massenproduktion," in Proceedings of the 1st International Scientific-Practical Conference-Economics and Management, K. Tenekedschiew, Ed., Business and Public Sectors in the Economic Crisis-Problems and Perspectives, pp. 278-284, Technische Universität Varna, 2010.

[104] F. Maaser, Organisationsformen der Instandhaltung. Theoretische Grundlagen, Organisationsprinzipien und Gestaltungsansätze, Shaker, Aachen, Germany, 2014.

[105] M. Hammer and J. Champy, Reengineering the Corporation. A Manifesto for Business Revolution, HarperBusiness, New York, NY, USA, 1993.

[106] K. Löhr, Innovationsmanagement für Wirtschaftsingenieure, Oldenbourg, München, Germany, 2013.

[107] A. Picot, H. M. Dietl, and E. Franck, Organisation. Eine ökonomische Perspektive, Schäffer-Poeschel, Stuttgart, Germany, 2008.

[108] G. Schreyögg and J. Sydow, "Organizing for fluidity? Dilemmas of new organizational forms," Organization Science, vol. 21, no. 6, pp. 1251-1262, 2010.

[109] T. Nebl and H. Prüß, Anlagenwirtschaft, Oldenbourg, München, Germany, 2006.

[110] A. Mc Kinlay and K. Starkey, "Competitive strategies and organizational change," Organization Studies, vol. 9, no. 4, pp. 555-571, 1988. 

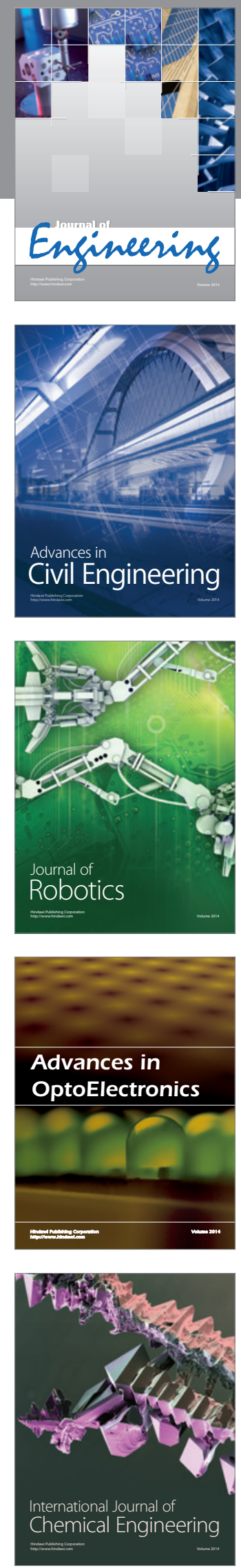

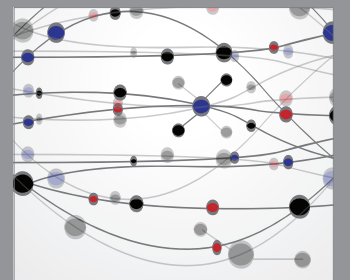

The Scientific World Journal
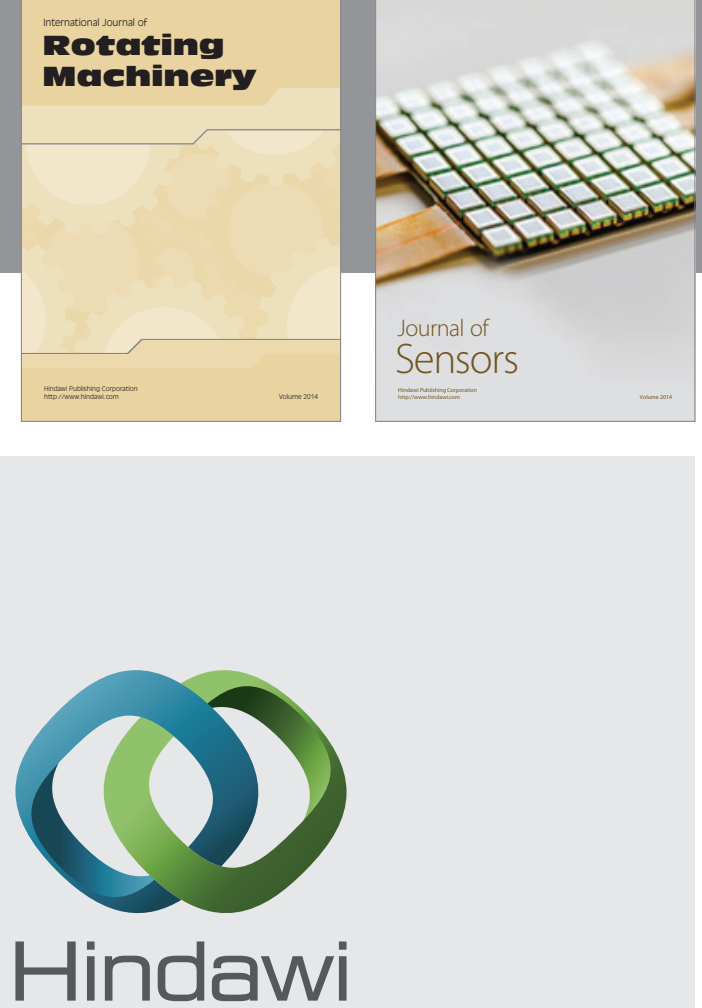

Submit your manuscripts at http://www.hindawi.com
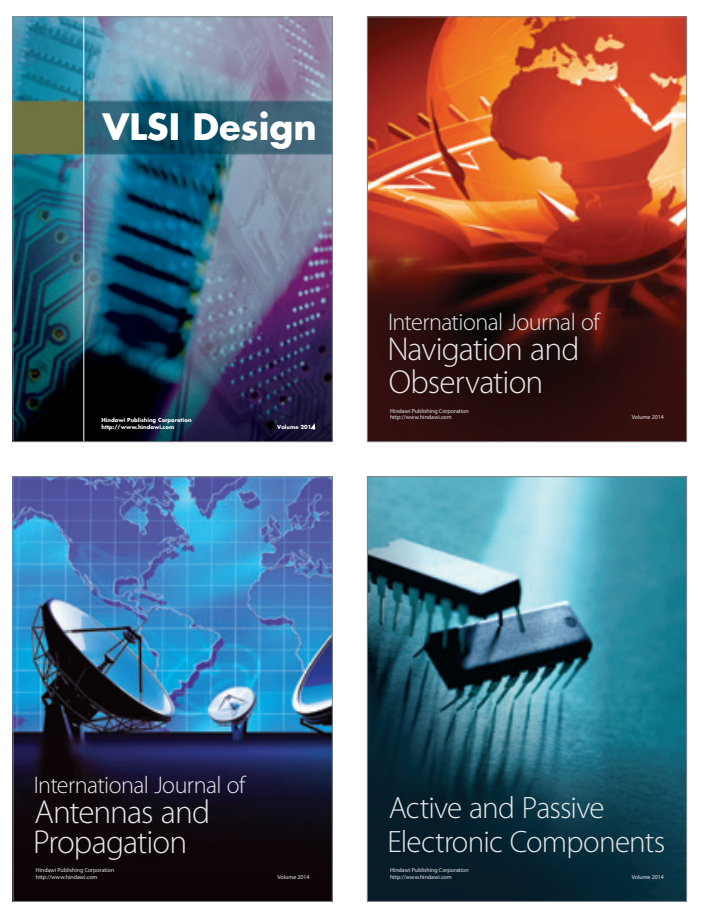
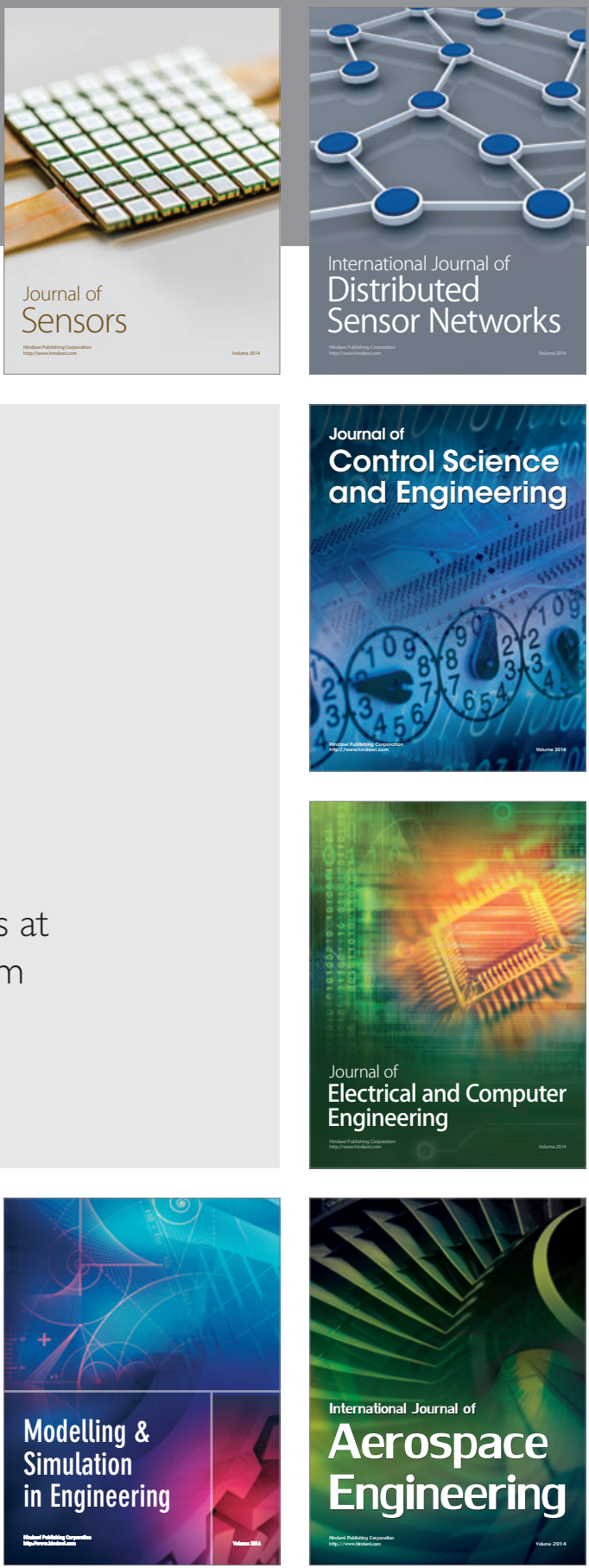

Journal of

Control Science

and Engineering
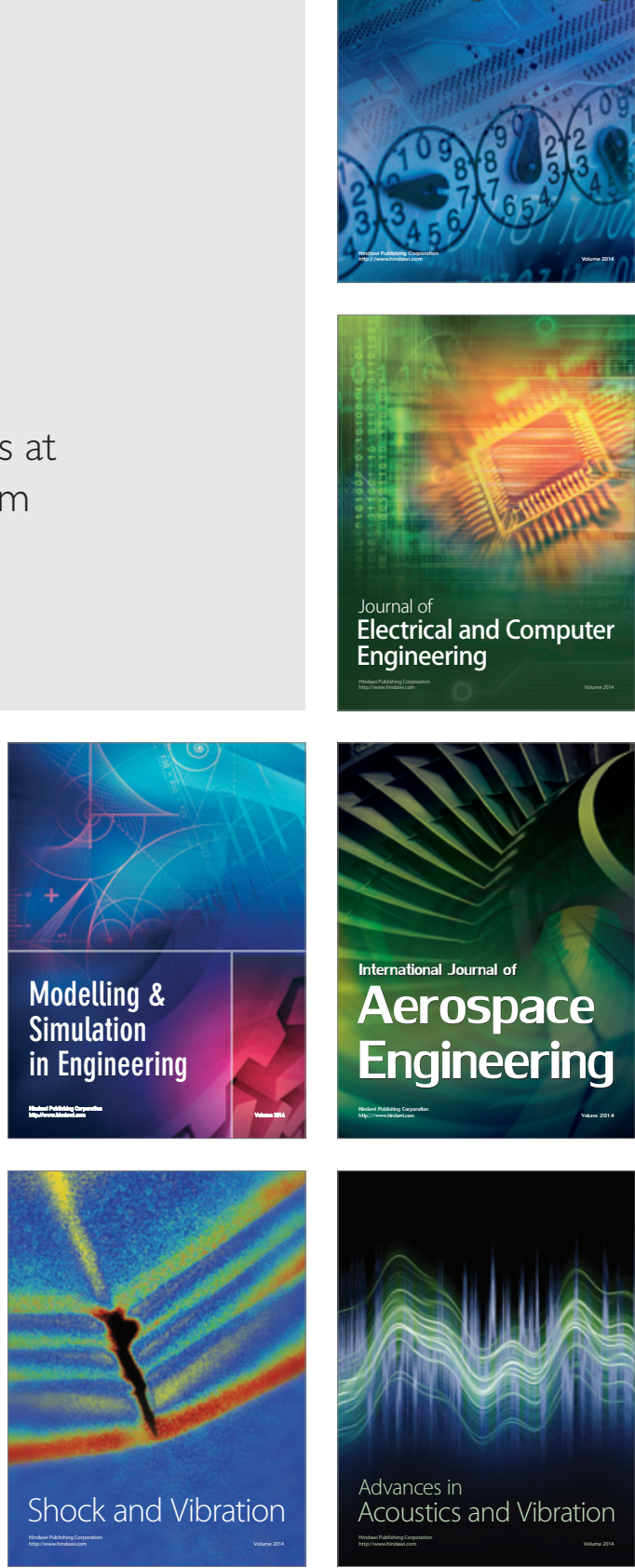